\title{
Transport and dispersion of atmospheric sulphur dioxide from an industrial coastal area during a sea-breeze event
}

C. Talbot $^{1}$, C. Leroy ${ }^{2}$, P. Augustin ${ }^{2}$, V. Willart ${ }^{1}$, H. Delbarre ${ }^{2}$, M. Fourmentin ${ }^{2}$, and G. Khomenko ${ }^{1}$

${ }^{1}$ Ecosystèmes Littoraux et Côtiers (CNRS FRE 2816), Université du Littoral - Côte d'Opale, 62930 Wimereux, France

${ }^{2}$ Laboratoire de Physico - Chimie de l'Atmosphère (CNRS UMR 8101), Université du Littoral Côte d'Opale, 59140 Dunkerque, France

Received: 27 September 2007 - Accepted: 26 October 2007 - Published: 14 November 2007

Correspondence to: C. Talbot (charles.talbot@univ-littoral.fr)

ACPD

Gaseous sulphur dioxide in a sea-breeze event

C. Talbot et al.

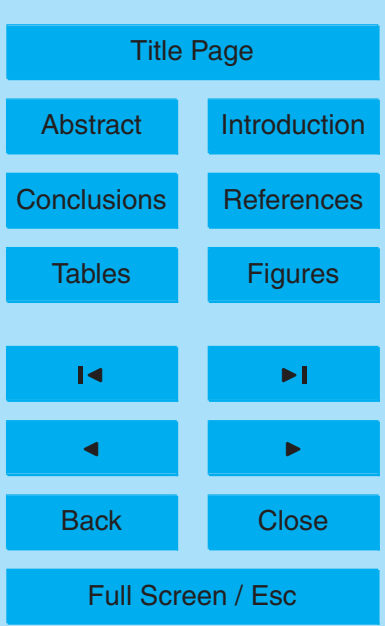

Printer-friendly Version

Interactive Discussion 


\section{Abstract}

Experimental and modelling results of the dynamics of a sea-breeze event and its effects on the three-dimensional (3-D) redistribution of the gaseous $\mathrm{SO}_{2}$ are presented within the framework of a particularly flat and industrialized coastal area of the North

5 Sea. The measurements were carried out at ground level with the stations of the local air quality monitoring agency and with two optical remote sensing instruments. The remote sensing setup consisted of a lidar and a sodar whose measurements allowed us to determine the layers of the lower troposphere during a sea-breeze event up to $1400 \mathrm{~m}$ height. The experimental results and measurements of industrial $\mathrm{SO}_{2}$ in the atmosphere are compared to the numerical simulations of the 3-D atmospheric nonhydrostatic chemistry model Meso-NH-C. The transport and the dispersion of gaseous $\mathrm{SO}_{2}$ are studied above the neighbouring industrial and urban areas. We show how the evolution and the redistribution of the $\mathrm{SO}_{2}$ concentrations at ground level are related to the structure and the dynamics of the sea breeze. The gaseous $\mathrm{SO}_{2}$ is brought back inland as soon as the sea breeze commences, mixed inner the thermal internal boundary layer and transported inland by the gravity current up to the sea-breeze front, where gases and particles are uplifted. The elevation of the polluted air masses by the sea-breeze system favours the nucleation of the emitted compounds due to the increase of the relative humidity in the uplifted layer. We show how the dynamical conditions during and after the sea breeze lead to storage of $\mathrm{SO}_{2}$ near and above the emitting industrial coastal areas, and favour the formation of acidic aerosol particles.

\section{Introduction}

For commercial installations, the industrial activity is highly developed in coastal areas, leading to a concentration of plants likely to cause serious pollution events. This risk comes from the continuous emission of aerosols and gaseous pollutants resulting from common industrial activity, and also from one-off, unavoidable incidents or acci-

\section{Gaseous sulphur dioxide in a sea-breeze event \\ C. Talbot et al.}

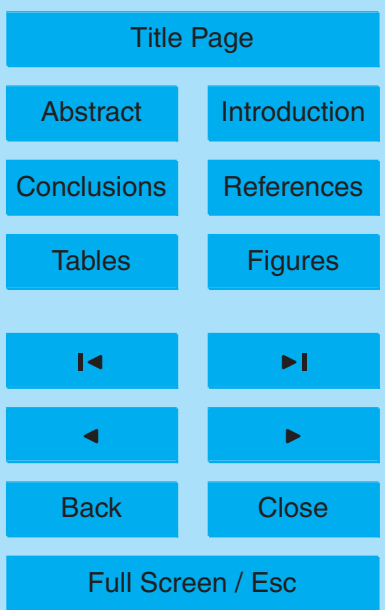

Printer-friendly Version

Interactive Discussion 
dents in the industrial processes. In such a coastal context, the sea breeze represents a critical meteorological phenomenon which acts on the transport and dispersion of the atmospheric pollutants, and leads to high pollution levels near the ground and to a lift effect carrying pollutants into the more elevated layers (Stull, 1988; Miller et al., 5 2003). The sea breeze is actually a complex phenomenon whose dynamics radically change the structure of the lower troposphere, and which relies heavily on the meteorological synoptic conditions and the local topography (Physick, 1980; Abbs, 1986; Venkatram, 1986; Durand et al., 1989; Garratt, 1990; Luhar et al., 1998; Steyn, 1998; Kouchi et al., 1999; Nazir et al., 2005; Augustin et al., 2006). The air quality fore10 casting within an industrialized coastal area requires a very fine understanding of the sea-breeze features and dynamics (Stull, 1988; Ohba et al., 1998; Mahrt, 1999; Srinivas and Venkatesan, 2005; Harris and Kotamarthi, 2005). In this paper, we use field experiments and numerical simulations to analyse the impacts of the sea-breeze occurrence on the local and the regional pollution above a flat industrialized region. The 15 research campaign relies on remote sensing with lidar and sodar systems, and local meteorological and air quality measurements, to identify the sea-breeze event and the pollution episode and validate the Meso- $\mathrm{NH}-\mathrm{C}$ numerical simulation.

As a tracer of the industrial emissions, we have chosen the gaseous $\mathrm{SO}_{2}$ among the wide variety of the emitted industrial compounds. The gaseous $\mathrm{SO}_{2}$ is well known as a precursor for sulphuric acid particles $\left(\mathrm{H}_{2} \mathrm{SO}_{4}\right)$ involved in acidic deposition, global climate, and global ozone layer (Jacobson, 2002). The effects of acid deposition include the acidification of surface waters and the subsequent damage to aquatic ecosystems, the harm to forests and vegetation, as well as the corrosion of materials and structures (Seinfeld and Pandis, 1998). Emissions of sulphur dioxide particles can affect humidity 25 and cloud formation as in the stratosphere (Noholt et al., 2005). The accretion of acid particles to water droplets and the formation of acid clouds are two major processes for acidic depositions. A feature of industrial areas is the emission of plumes with high sulphur dioxide concentration. The understanding and the forecasting of the atmospheric events leading to the formation of acid deposition is thus of importance. Half of the
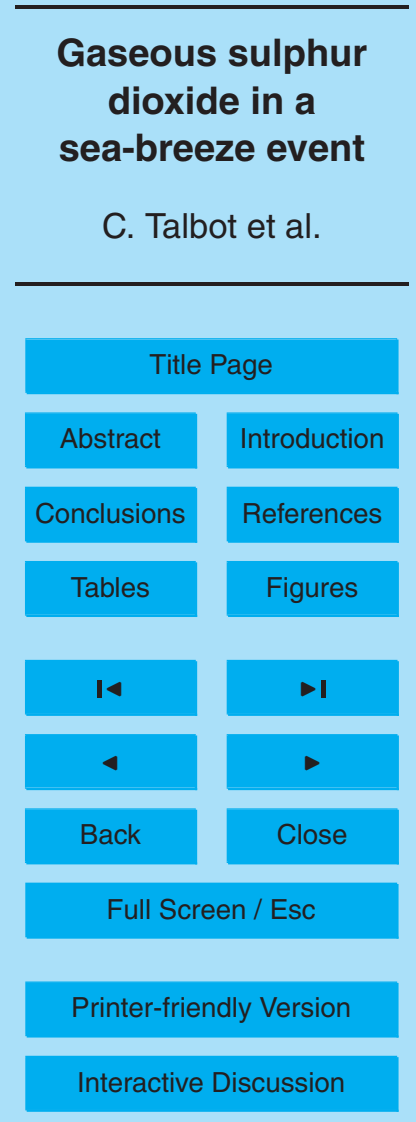
$\mathrm{SO}_{2}$ concentration disappears by oxidation in the first ten kilometres from its source of emission (Hewitt, 2001), the lifetime of the $\mathrm{SO}_{2}$ is about a day (Hains, 2007), which is comparable with the space-time scale of the sea-breeze phenomenon. Thus the transport and dispersion by sea-breeze is indispensable to understanding air pollution 5 in the coastal zone.

The study began on 15 September 2003, in a French industrial area of the North Sea, namely the Flanders region, which is a coastal plain characterized by a flat topography up to $40 \mathrm{~km}$ away from the coastline, and where the highest hill rises to $200 \mathrm{~m}$ above sea level (a.s.l.), such that we can consider sea-breeze events in this area as simplified 10 sea-breeze cases. The occurrences of the sea-breeze phenomenon during the year 2003 reached 70 sea breezes in the Flanders littoral of the Nord Pas de Calais region (source: ATMO Nord Pas de Calais). For $30 \%$ of the sea breezes recorded at the Saint Pol sur Mer meteorological station, a southern wind blew above the city before the onset of the breezes. In such a configuration, the wind is opposed to the inland propagation of the sea-breeze flow. We will be studying this precise meteorological condition which is a representative case of sea-breeze phenomenon in the Flanders area.

The chosen industrial area spreads along the Dunkerque coastline on the French side of the Flanders area, but it could have been in any of the neighbouring industrial sites such as London or Antwerp. Figure 1 shows the city and the nested domains which are used in the Meso- $\mathrm{NH}-\mathrm{C}$ numerical simulations. As in many equivalent industrial ports, the city developed in the 70's at the vicinity of the industries, so that its 210000 inhabitants live very close to the pollution sources. It is also located north of the Nord-Pas de Calais region, which is one of the most densely populated regions of France with 4 millions inhabitants. The main $\mathrm{SO}_{2}$ sources in this industrial area are the petrochemistry and iron and steel metallurgic activities. The cumulated $\mathrm{SO}_{2}$ emissions have been estimated at 22340 tons for the year 2000 by the authorities in charge of the surveillance of the industry (DRIRE-Direction Régionale de l'Industrie, de la Recherche et de l'Environnement). In a study devoted to volatile organic compounds,

\section{Gaseous sulphur dioxide in a sea-breeze event \\ C. Talbot et al.}

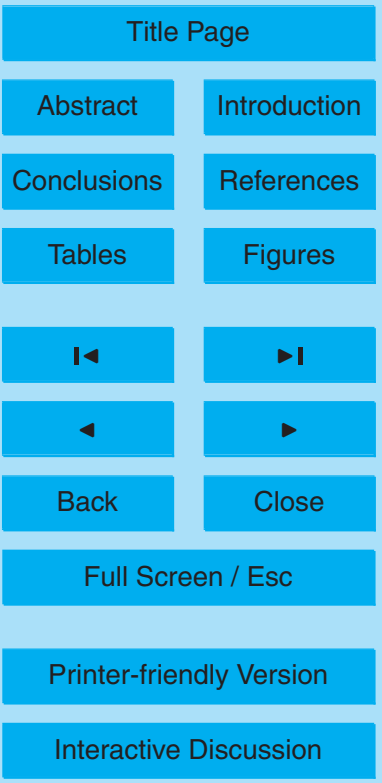


the city's background pollution has been proven to come from urban sources, but major pollution phenomena can be attributed to the industrial emissions (Badol et al., 2007). Measurements of acid PH as low as 2.8 in 2001 have already shown the acidity of the rain precipitations in this area (Ledoux, 2003). According to Whelpdale and Miller 5 (1989) during the Background Air Pollution Monitoring Program of the World Meteorological Organization, rain precipitations in northern Europe are known to be among the lowest $\mathrm{PH}$ levels worldwide. Along the Dunkerque coastline, the $\mathrm{SO}_{2}$ ground pollution is featured by high peaks with a concentration of a few hundreds $\mu \mathrm{g} \mathrm{m}^{-3}$; for instance, the local authorities for air quality monitoring recorded a $920 \mu \mathrm{g} \mathrm{m}^{-3}$ in 2002 (April 10 2002; source: Bulletin de l'air $n^{\circ} 100$, ATMO Nord Pas de Calais). The occurrence of sea breezes in the Dunkerque coastal area is at the origin of preventive actions which justified a specific meteorological study to understand the processes involved in the transport and the dispersion of these locally emitted pollutants.

This paper is organized as follows. In Sect. 2, the structure of the lower troposphere 15 and its dynamics during the sea-breeze period will be described from the experimental and modelling results. In the next section, the ground-level distribution of the $\mathrm{SO}_{2}$ concentration from the air-quality monitoring stations will be analysed with regard to the main steps of the sea-breeze dynamics. The 3-D non-hydrostatic model Meso$\mathrm{NH}-\mathrm{C}$ will help explaining the $\mathrm{SO}_{2}$ transport and dispersion in Sect. 4. Finally, the role 20 of the sea-breeze system on the redistribution of the pollutants will be discussed in Sect. 5 as well as the evolution of the atmospheric environment in which pollutants are released.

\section{Dynamics and structure of the lower troposphere}

The study took place on 15 September 2003, during which a high pressure system 25 was observed on Germany and Central Europe, while low pressures were located in the north of Norway. A light south-east synoptic wind blew above the studied area during the morning. During the sea-breeze period, the sea-breeze flow was com-

\section{Gaseous sulphur dioxide in a sea-breeze event \\ C. Talbot et al.}

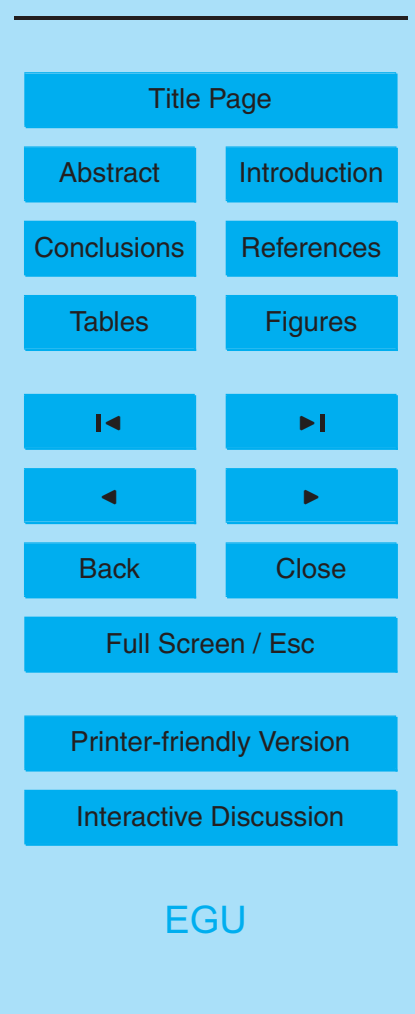


ing from the north and was thus opposite to the synoptic wind, both perpendicular to the coastline. Then the synoptic wind veered progressively to a north-westerly direction in the afternoon. In the paper (Talbot et al., 2007), the sea-breeze dynamics for this day were determined by analysing the measurements from the ground-based lidar 5 and sodar, the meteorological measurements and the numerical simulations with the non-hydrostatic mesoscale model Meso-NH (the experimental set is described in the Sect. 2.2 and illustrated by Fig. 2). For clarity, in this paper we have only repeated the main results concerning the sea-breeze dynamics and the atmospheric structure, which will be further used to analyse the conditions of transport of pollutants and their 10 changing environment.

\subsection{Sea-breeze dynamics}

The sea breeze onset was determined by locating the sea-breeze front on the time series of the wind speed and direction. A sudden change of the wind direction from south-easterly to northerly in this case and a progressive increase of the wind speed 15 have shown that the sea-breeze began at 11:00 UTC on the Dunkerque coastline. The temperature, the wind direction and the wind speed simulated by the model have been successfully compared with the measurements at the meteorological stations. The computed temperatures and the wind directions were found to be in close agreement with the measured ones, while the wind speeds were slightly underestimated by the model. For the studied day, the modelled onshore flow initiated by the sea-breeze extends up to $50 \mathrm{~km}$ inland from the Flanders coast, before veering clockwise due to the effect of the Coriolis' force.

An acceleration of the sea-breeze flow was observed at the ground stations and also simulated by the model. The duration of this acceleration was estimated to $210 \mathrm{~min}$ 25 beginning from the sea breeze onset. Significant consequences of this acceleration on the atmospheric dynamics followed:

- The turbulence in the sea-breeze front intensified and the vertical dimension of 15994

\section{Gaseous sulphur dioxide in a sea-breeze event}

C. Talbot et al.

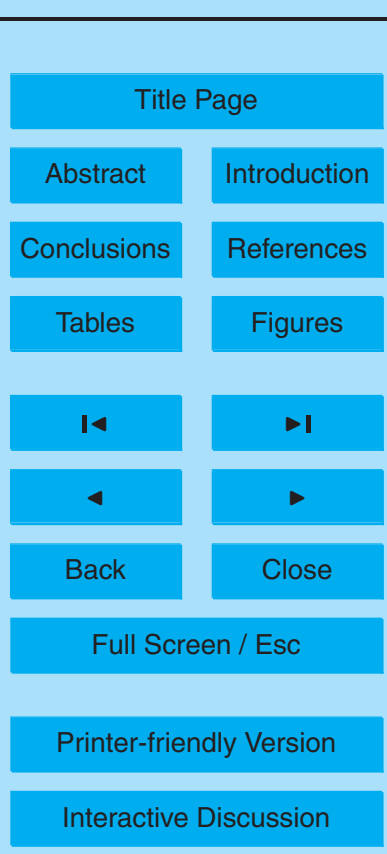


the front was growing as the gravity current accelerated.

- The sea-breeze front brought up air masses from the gravity current in the above layers.

- The marine air masses in the gravity current were redistributed in altitude by the breeze front and transported by the synoptic wind in a seaward recirculation zone just above the gravity current; that increased the amount of humidity in the upper layers. Thus the sea-breeze system consequently stratified the inland lower troposphere with this inflow of fresh marine air.

2.2 Atmospheric stratification from ground-based remote sensing instruments and modelling results

The structure of the lower troposphere and its evolution were deduced from the measurements of the lidar and the sodar, both located at Petite-Synthe, $6 \mathrm{~km}$ away from the coastline (Fig. 2). The stratification of the lower troposphere was first determined from the lidar measurements by using the contrast of the aerosols distribution between consecutive layers, which induces a corresponding contrast of their light scattering properties. A transition between 2 layers is then generally featured by a jump of the lidar signal associated with the backscattering variation through the layers transition. The inflexion point method (IPM) using this property (Menut et al., 1999; Chen et al., 2001) was employed to determine the stratification. The thermal internal boundarylayer (TIBL) thickness has been measured and an upper highly reflective layer (HRL) has also been detected. The acoustic sodar system provided further informations on the vertical wind profile, up to $750 \mathrm{~m}$, and also on the vertical structure of the atmosphere thanks to the echo and the variance of the vertical wind velocity $\sigma_{w}^{2}$. The seabreeze gravity current top was localized at the highest altitude with a north-easterly wind direction. The TIBL was identified by the turbulence activity measured with the vertical velocity variance $\sigma_{w}^{2}$. The sea-breeze front was also detected within the sodar

\section{Gaseous sulphur dioxide in a sea-breeze event \\ C. Talbot et al.}

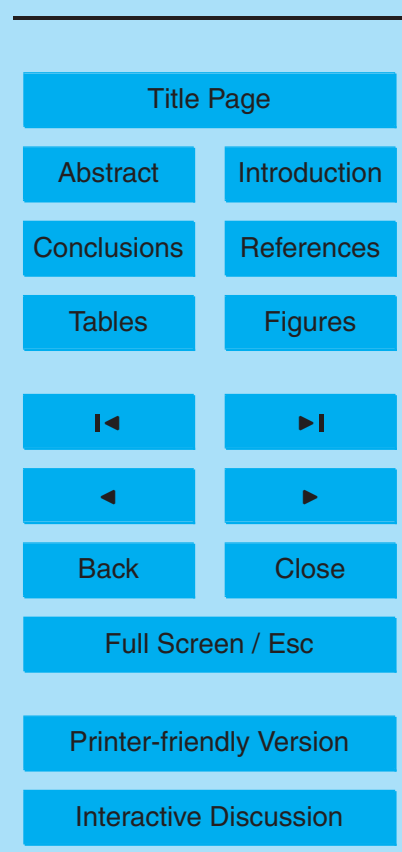

EGU 
range between 12:30 UTC and 13:30 UTC thanks to the high acoustic echo due to turbulence.

The stratification of the sea-breeze system is reported in Fig. 3 and hereafter discussed. The lidar and the sodar both show a TIBL with a stationary thickness around 5 150-200 m from 13:30 UTC to 17:00 UTC. The TIBL thickness decreases down to about $100 \mathrm{~m}$ until 20:00 UTC. The gravity current layer top can be observed on the sodar wind profiles between 15:00 UTC and 20:00 UTC, around 350-400 m before decreasing down to $300 \mathrm{~m}$ in the late afternoon (red circles in Fig. 3). The gravity current also corresponds to the top of the HRL observed by the lidar (white rectangles in

10 Fig. 3). It should be noted that the continental boundary layer is advected above the sea-breeze system by the southerly synoptic wind and can also be observed by the lidar around 1000-1100 m (not drawn here). Finally, a stable multilayer structure was also observed with the lidar from 19:00 UTC and will be discussed in Sect. 5.

The Meso-NH numerical simulations are in agreement with the structure and the dy15 namics of the sea breeze detected by the remote sensing instruments and the groundbased meteorological data. The turbulence and the vertical ascents were clearly shown to increase in the vicinity of the sea-breeze front inside the sea-breeze system. The top of the TIBL was marked by a decrease of the water vapour mixing ratio. The humidity of the TIBL resulted from the onshore mixing of the thin Marine Boundary Layer (MBL) (about $100 \mathrm{~m}$ ) inside the TIBL. Peak values of the water vapour mixing ratio were located just above the gravity current. The sea breeze system comprises air masses coming offshore from the MBL which increase in altitude by means of vertical ascents in the sea-breeze front. The headwind, located between $500 \mathrm{~m}$ and $1000 \mathrm{~m}$ above sea level (a.s.I.) and behind the sea-breeze front, was also simulated. This headwind was characterized by its significant offshore subsiding wind. The offshore flow transported the air masses swept upwards by the front and blended them by shearing at an altitude just above the gravity current.

\section{Gaseous sulphur dioxide in a sea-breeze event \\ C. Talbot et al.}

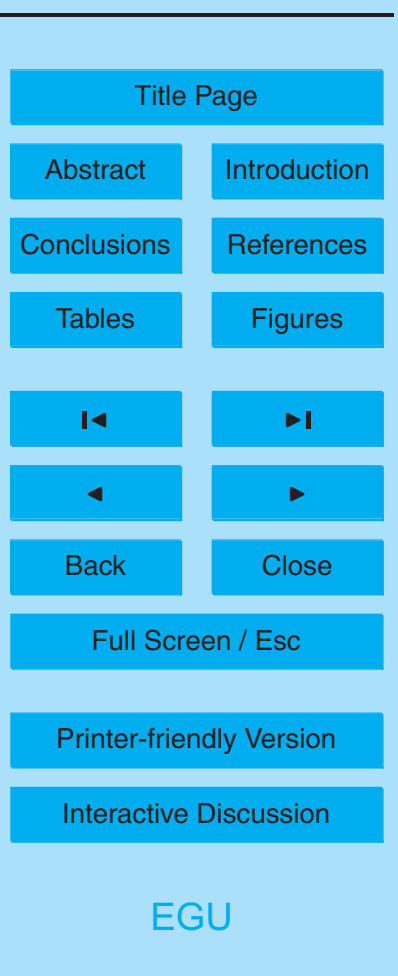




\section{Ground-level observation of the $\mathrm{SO}_{2}$ redistribution by the sea-breeze}

\subsection{The air quality monitoring network}

Regulated gaseous pollutants are being monitored by a local organization, called ATMO Nord - Pas-de-Calais. Figure 2 illustrates the distribution along the coastline 5 of the air quality monitoring ground stations (blue dots) as well as the major sources of emitted $\mathrm{SO}_{2}$ (yellow dots). The $\mathrm{SO}_{2}$ concentrations are measured, in the Dunkerque area, by eight air quality monitoring stations. Table 1 shows the classification of each station into one of four categories (traffic, suburban, urban and industrial) used by the French environment administration (ADEME) for defining the target pollutants of each station. The main stations of the Dunkerque area are categorised as "industrial". One station categorised as "traffic", DK2 station, is located eastward of the industrial area, and two other stations categorised as "urban" (DK8 and DKB stations) are located southward of the industrial area.

\subsection{Time series of the $\mathrm{SO}_{2}$ ground concentration}

15 Before the sea-breeze onset, pollutants released by the industrial and urban sites were carried seaward by the south-easterly synoptic wind. When the sea breeze started, the flow direction near the ground reversed and brought the pollutants back landward. Figures $4 \mathrm{a}$ to $\mathrm{h}$ show the as-measured $\mathrm{SO}_{2}$ concentrations with a fifteen minutes averaging time, at the eight air quality monitoring stations. The passage of the sea-breeze front above each station is indicated by a vertical dashed red line; this was determined from the measurements of the nearest meteorological ground station. The sea-breeze onset is indicated on the time series of the air pollutants by peaks of the $\mathrm{SO}_{2}$ concentration, which were observed at the stations downwind of the sources (DK5, DK7 and $D K B$ ) in the south of the industrial area (Fig. $4 c, d$ and f). Although stations DKC and DKD are close to the industrial area, the sea-breeze effect on these stations was not immediate (Fig. $4 \mathrm{~g}$ and $\mathrm{h}$ ), because they are located too westerly from the main

\section{Gaseous sulphur dioxide in a sea-breeze event \\ C. Talbot et al.}

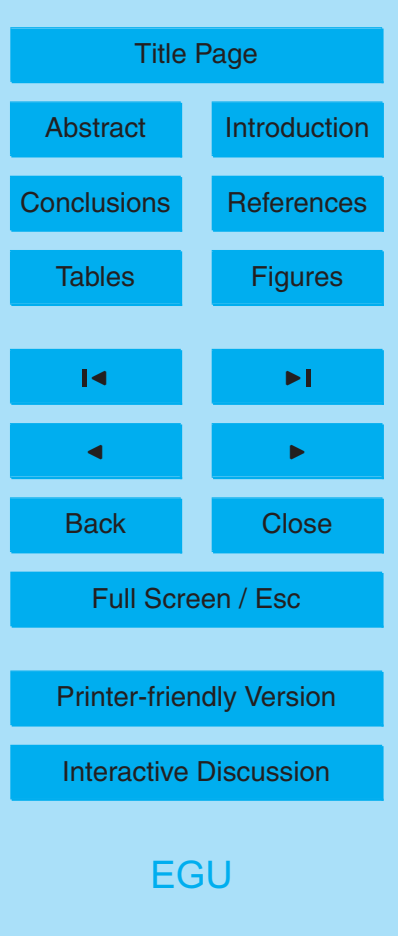


sources. Station DK3, located on the seashore in the north of the industrial area, had high concentrations before the sea-breeze front passage, due to the influence of the industrial fumigations under a south-easterly flow (Fig. 4b). For this station, the $\mathrm{SO}_{2}$ concentration reached its peak before the sea-breeze onset and then decreased dur-

5 ing the sea-breeze period. The stations DK2 and DK8 are located respectively east and south-east of the industrial area, and were not downwind of the industrial sources during the sea-breeze event (Fig. $4 \mathrm{a}$ and e). Low increases in the $\mathrm{SO}_{2}$ concentrations were observed for some stations $\left(35 \mu \mathrm{g} \mathrm{m}^{-3}\right.$ at DK2 and $20 \mu \mathrm{g} \mathrm{m}^{-3}$ at DK8) after the passage of the sea-breeze front. As for DK3, this station was not directly subjected to 10 the pollutants sources and their measured concentration of a few tens of $\mu \mathrm{g} \mathrm{m}^{-3}$ gives an idea of the seaward pollution generated before the sea breeze under the southeasterly wind.

\section{Modelling of the 3-D transport and dispersion of the $\mathrm{SO}_{2}$ by the sea-breeze}

Because the ground observations are sparse and the range of the remote-sensing 15 measurements is only a few kilometres, numerical simulations were conducted to provide the greater spatial scale of the sea-breeze system (some tens of kilometres). The 3-D numerical simulations give a complementary tool to describe in a continuous spatiotemporal way the sea-breeze system and complete the set of the measurements for a better understanding of the lower troposphere dynamics and pollutants dispersion.

\subsection{The Mesoscale Non Hydrostatic Chemistry (Meso-NH-C) model}

The standard version of the atmospheric non-hydrostatic model Meso-NH has been jointly developed by the French "Centre National de Recherches Météorologiques" (CNRM) and the "Laboratoire d'Aerologie" (CNRS) (Lafore et al., 1998). The model is used here with grid nested fields in the standard configuration, with the following parameterizations: ISBA surface scheme (Noilhan and Planton, 1989; Noilhan and Mah-

\section{Gaseous sulphur dioxide in a sea-breeze event \\ C. Talbot et al.}

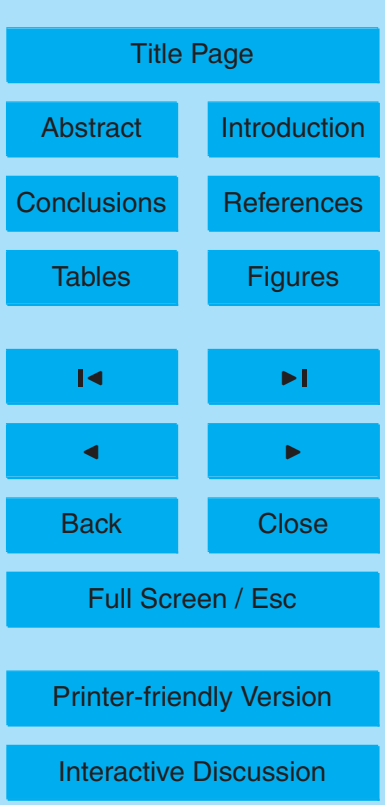


fouf, 1996; Calvet et al., 1998; Boone et al., 1999), urban surface scheme (Masson, 2000), ECMWF radiation scheme (Morcrette, 1991), 1D turbulence for low horizontal resolution fields (Bougeault and Lacarrere, 1989), 3-D turbulence and large-eddy simulation mode (Deardorff, 1972; Cuxart et al., 2000) for the highest horizontal reso5 lution field. Sea-surface fluxes were calculated using the Charnock relation (Charnock, 1955).

Meso-NH was coupled to the chemical model Meso-NH-C to compute the transport and the dispersion of chemical pollutants (Stockwell et al., 1997, Tulet et al., 2000, Mari et al., 2000, Tulet et al., 2003). The simulations, starting at 00:00 UTC to 24:00 UTC, 10 were carried out using outputs of the ARPEGE models (Déqué et al., 1994) for the initial and boundary conditions for the day of 15 September 2003. The simulations were done with 2 nested models whose domains are superimposed over the geographic area in Fig. 1. The model with a 5-km horizontal resolution covers the north of France, the south-east of England and a part of Belgium, and spreads over $320 \mathrm{~km}$ from north to south and from east to west. The inner $1-\mathrm{km}$ resolution model is centred on Dunkerque with 64 by 64 grid mesh points and a 2-s time step. The vertical grids include 50 levels up to $3000 \mathrm{~m}$ a.g.l. with a first level at $10 \mathrm{~m}$ above the ground.

The chemical reactions were computed with the reduced chemical scheme RELACS for aqueous-phase chemistry (Crassier et al., 2000) and dry deposition was activated (Wesely, 1989). The wet deposition was still at a development stage and thus not taken into account in this version of the model. The 37 chemical elements used in the RELACS scheme were set at low ratios of concentration in the atmosphere at the onset of the simulation. The industrial $\mathrm{SO}_{2}$ emission rates were estimated from the cumulated annual emissions declared by the four main companies indicated on Fig. 2 (DRIRE, 2001). These specific sources were positioned on the grid-mesh in a 1-km resolution model and the surface emissions rates were computed by averaging these emissions on the mesh surface. In this way, the position and the relative weight of the sources are taken into account in the simulation, but we must note here that this gives an approximation of the instantaneous emission rates, because the simulation does

\section{Gaseous sulphur dioxide in a sea-breeze event \\ C. Talbot et al.}

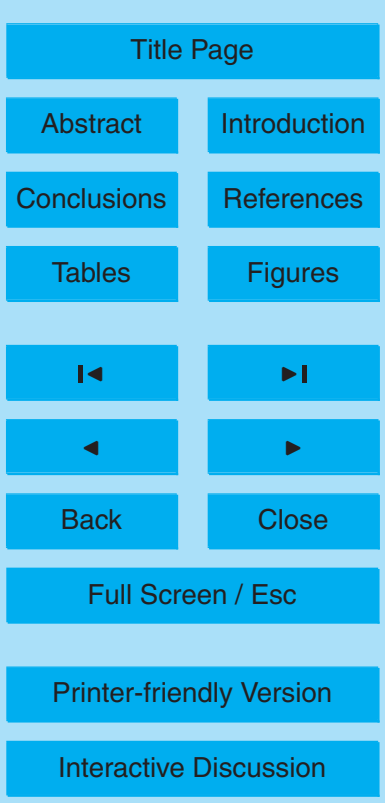


not include the temporal variability coming from the industrial processes and activities. The computed concentration of $\mathrm{SO}_{2}$ has then to be interpreted in a qualitative way.

4.2 The sea-breeze system and the $\mathrm{SO}_{2}$ three-dimensional distribution

Figure 5 represents a comparison of the observed and the computed evolution of the 5 normalized concentration of $\mathrm{SO}_{2}$ at the stations DKB and DKD, which are close enough to be downwind of the sources at the sea-breeze onset. The concentration is accurately reproduced in time by the model for DKB (Fig. 5a) when the sea breeze brought the pollutants back. However, the computed peak of pollution at DKD appeared later than it actually did (according to measurements) (Fig. 5b) due to a slight variation in the wind direction. The DKD station was downwind of the industrial plumes later in the model. At this scale and considering the proximity between the stations and the emitting plants, a precise comparison of the experimental and computed concentrations would need a higher model resolution and a fine modelling of the industrial plumes which is beyond the scope of this paper.

15 The distribution of the $\mathrm{SO}_{2}$ concentration inside the sea-breeze system is illustrated in Fig. $6 \mathrm{a}$ and $\mathrm{b}$ representing horizontal maps of the concentration along the sea shore (white plain line) at a 10-m and 350-m altitude a.g.l. The landward advection of $\mathrm{SO}_{2}$ is located either inside the MBL (above the sea) or inside the TIBL (inland), and is clearly limited by the sea-breeze front (Fig. 6a), while the seaward advection of $\mathrm{SO}_{2}$ stands 20 above the gravity current (Fig. 6b). The $\mathrm{SO}_{2}$ concentration at the 10-m level increases by travelling above the industrial area (Fig. 6a) up to the sea-breeze front, and delimiting thus an area where high concentrations can be found. This is in agreement with the ground-stations downwind of the industrial sources (DK5, DK7 and DKB), showing higher concentration as the sea-breeze front passes over. The TIBL trapped and 25 mixed the pollutants released by the ground sources. The gravity current carried them horizontally inland up to the sea-breeze front where they were carried up and mixed.

Figure 7 shows a vertical view of the $\mathrm{SO}_{2}$ concentrations along a north-south line. Once the pollutants were being moved in altitude by the sea-breeze front, they were

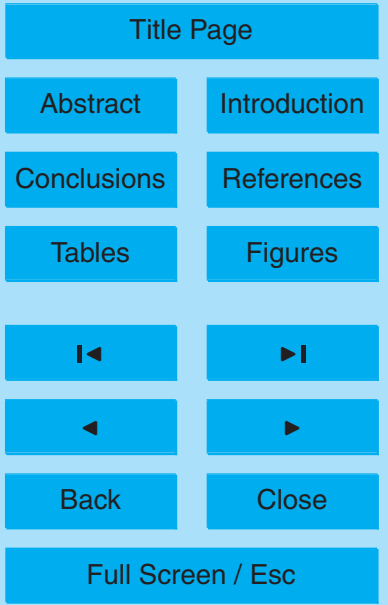

Printer-friendly Version

Interactive Discussion 
distributed seaward by the headwind, located in altitude at the top and behind the sea-breeze front. The shearing between the synoptic wind and the opposite gravity current created an area of low wind speed, where the pollution remains just above the gravity current. Transport of pollutants was governed at this altitude by the synoptic 5 wind while the gravity current was developing inland, perpendicularly to the coastline, in accordance with Gilliam et al. (2004).

\section{Signature of the sea-breeze on the air pollution at local and regional scales}

The signature of the sea-breeze on the air pollution at local and regional scales is seen through the $\mathrm{SO}_{2}$ transport and dispersion in the numerical simulations. The use of $\mathrm{SO}_{2}$ 10 as a tracer of the industrial emissions helps in understanding the consequences of the sea-breeze event on the general environmental evolution of gaseous and aerosols pollution in the lower layers of the troposphere.

\subsection{Ground-level pollution at local and regional scale}

At ground level, the stations' measurements showed that the sea breeze has immediate and lasting consequences on the local pollution near the sources, as soon as the sea breeze started. Since the vertical mixing is limited to the height of the thin TIBL, the trapping and mixing of the released pollutants inside the TIBL led to instantaneous high-level pollution at stations downwind of the industrial sources (DK5, DK7 and DKB). On the other hand, some stations became isolated from the direct emissions (DK3 in Fig. 6a), but their measurements revealed a background pollution with somewhat elevated $\mathrm{SO}_{2}$ concentration instead of clean maritime air (Fig. 4b). This latter observation shows that the local pollution is not only related to the main sources but also that it cannot be isolated from the history of the pollution in the area. In this example, an offshore reservoir was created before the sea-breeze onset, and the reversing of the wind brought back this pollution, which added to the direct industrial emissions under

\section{Gaseous sulphur dioxide in a sea-breeze event \\ C. Talbot et al.}

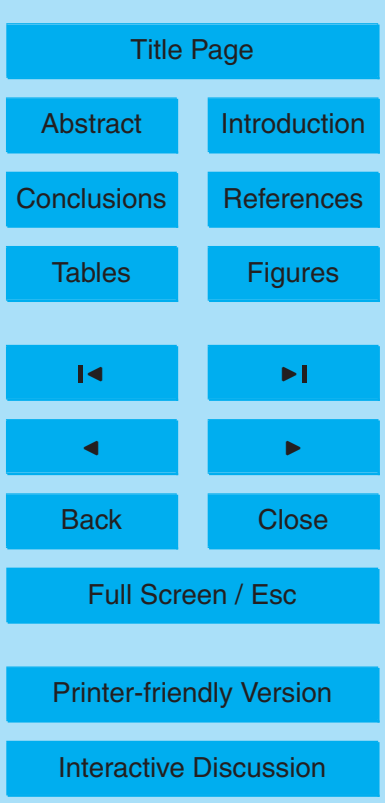


the sea-breeze. The trapped pollutants are channelled up to the sea-breeze front and this ground-level pollution was delimited by the front line and thus concerns the regional scale.

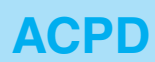

\subsection{Pollution of the lower troposphere}

5 On reaching the sea-breeze front, the gaseous and aerosols pollutants remain in elevated layers. Figure 8 represents the redistribution of the lower troposphere pollutants at the end of the day and at a low altitude above the studied area. At $350 \mathrm{~m}$ a.g.l. and 17:00 UTC, the pollutants carried up by the front, were dispersed seaward over their emission area, above a remaining northern flow (Fig. 8a). At 18:00 UTC, the model showed peaks of the $\mathrm{SO}_{2}$ concentration whose altitude corresponded to the top of the $\mathrm{HRL}$ detected by lidar (Fig. 8b). In the evening, the air masses travelled slowly and remained in nearby areas with a rotation of the wind, veering progressively clockwise, most likely with the help of the Coriolis' force (Simpson, 1995) and the inland nocturnal radiative cooling. At this level, the lidar also indicated that the structure of the lower troposphere considerably changed during the evening. Figure $8 \mathrm{c}$ shows a lidar scan at 21:00 UTC showing that the lower troposphere has been more and more stratified as the night approached. The elevated pollution thus stayed in this stable multilayered structure during the night and its chemistry has to be linked with the physical properties of these layers.

$20 \quad$ At the mesoscale, during the night from 15 to the 16 September, the winds veered in an anticyclonic circulation around the English Channel Strait. Figure 9 superimposes the computed wind velocities and the distribution of the $\mathrm{SO}_{2}$ concentration at $300 \mathrm{~m}$ and 06:00 UTC on 16 September. This shows that the local pollutants were forced to remain near their areas of emission until the next day and the next sea breeze. The 25 gaseous $\mathrm{SO}_{2}$, and more generally the gaseous pollutants and aerosols, came back above or nearby the industrial coastal area and can therefore contribute significantly to the photochemical activity at the start of the new day, 16 September. The pollutant concentrations in the lower layers inside this stratified atmosphere is likely to decrease

\section{Gaseous sulphur dioxide in a sea-breeze event \\ C. Talbot et al.}

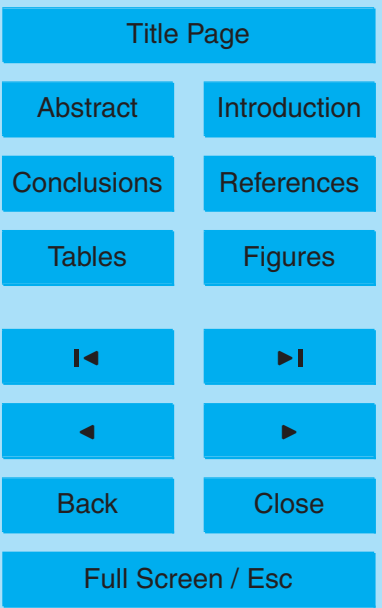

Printer-friendly Version

Interactive Discussion 
because of the wet and dry deposition and the intermittent bursts of turbulence activity during night time (Weber and Kurzeja, 1991; Poulos et al., 2002; Mahrt et al. 1998a; Coulter, 1990; Howell and Sun, 1999; Salmond, 2005).

\subsection{Effects on the aerosols and chemical compounds}

5 The sea-breeze front brought the pollution emitted from the coastal area and marine air from the MBL above the altitude of the gravity current. As a result, high values of $\mathrm{SO}_{2}$ concentrations, as well as a high mixing ratio of water vapour, were computed inside the TIBL and in the vicinity of the gravity current and above it. Therefore the pollutants emitted in the sea-breeze system stayed in an environment of relatively high humidity.

10 According to Khoder's work (2002), the conversion rate of $\mathrm{SO}_{2}$ into particles of sulphate is improved by high ratios of relative humidity and ozone concentrations. One of the mechanisms of conversion of $\mathrm{SO}_{2}$ leads to sulphuric acid gas $\left(\mathrm{H}_{2} \mathrm{SO}_{4}\right) . \mathrm{H}_{2} \mathrm{SO}_{4}$ has a low saturation vapour pressure and condenses easily onto particles (Marti et al., 1997). The conversion of $\mathrm{SO}_{2}$ to $\mathrm{H}_{2} \mathrm{SO}_{4}$ requires 3 steps: conversion to bisulphite $\left(\mathrm{HSO}_{3}^{-}\right)$, which reacts with oxygen to form sulphur trioxide $\left(\mathrm{SO}_{3}\right)$ and then reacts with water to form sulfuric acid, as indicated in Eqs. (1.1), (1.2) and (1.3).

$\mathrm{OH}_{(\mathrm{g})}+\mathrm{SO}_{2(\mathrm{~g})}+\mathrm{M}_{(\mathrm{g})} \rightarrow \mathrm{HSO}_{3(\mathrm{~g})}^{-}+\mathrm{M}_{(\mathrm{g})}$

$\mathrm{HSO}_{3(\mathrm{~g})}+\mathrm{O}_{2(\mathrm{~g})} \rightarrow \mathrm{SO}_{3(\mathrm{~g})}+\mathrm{HO}_{2(\mathrm{~g})}$

$\mathrm{SO}_{3(\mathrm{~g})}+\mathrm{H}_{2} \mathrm{O}_{(\mathrm{g})} \rightarrow \mathrm{H}_{2} \mathrm{SO}_{4(\mathrm{~g})}$

Where $\mathrm{M}$ is a molecule $\left(\mathrm{N}_{2}\right.$ or $\left.\mathrm{O}_{2}\right)$ which dissipates energy by collision.

Under the dynamic conditions of a sea breeze, the $\mathrm{SO}_{2}$ distributed and trapped by the sea breeze can enhance the concentration of sulphate particles in the elevated air layers due to a rising amount of relative humidity by adiabatic cooling. The other mechanisms of conversion of $\mathrm{SO}_{2}$ to particle phase are its dissolution into water-containing particles (Eq. 2) and then its aqueous-phase oxidation.

$$
\mathrm{SO}_{2(\mathrm{~g})}+\mathrm{H}_{2} \mathrm{O}_{(\mathrm{l})} \rightarrow \mathrm{H}_{(\mathrm{aq})}^{+}+\mathrm{HSO}_{3(\mathrm{aq})}^{-}
$$

\section{Gaseous sulphur dioxide in a sea-breeze event \\ C. Talbot et al.}

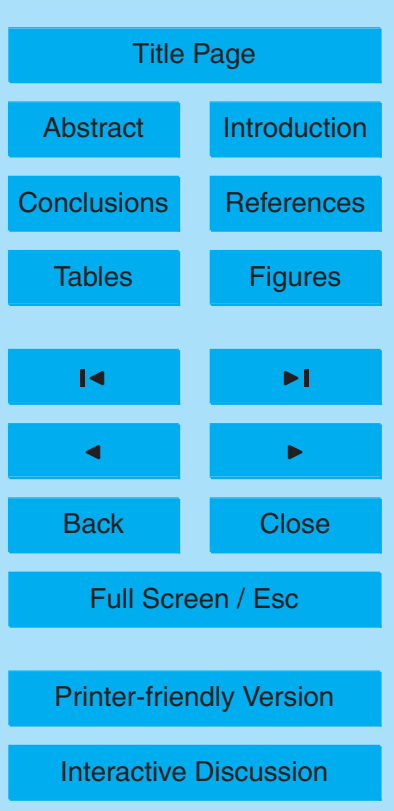

EGU 
There are 3 components intervening in the aqueous phase oxidation of $\mathrm{HSO}_{3}^{-}$: dissolved $\mathrm{O}_{2}$ (Eq. 3), dissolved $\mathrm{O}_{3}$ (Eq. 4) or dissolved $\mathrm{H}_{2} \mathrm{O}_{2}$ (not presented here).

The $\mathrm{O}_{2}$ oxidation is sensitive to the presence of catalysts such as $\mathrm{Mn}$ and $\mathrm{Fe}$, which increase the speed of the reaction.

${ }_{5} \mathrm{HSO}_{3(\mathrm{aq})}^{-}+1 / 2 \mathrm{O}_{2(\mathrm{aq})} \rightarrow \mathrm{H}_{(\mathrm{aq})}^{+}+\mathrm{SO}_{4(\mathrm{aq})}^{2-}$

$\mathrm{SO}_{4(\mathrm{aq})}^{2-}+2 \mathrm{H}_{(\mathrm{aq})}^{+} \rightarrow \mathrm{H}_{2} \mathrm{SO}_{4(\mathrm{aq})}$

Such reaction is likely to happen because of the presence of a Ferro-manganese factory at immediate proximity to the major $\mathrm{SO}_{2}$ source of the Dunkerque industrial area.

To be valuable, the following $\mathrm{O}_{3}$ oxidation needs sufficient ozone concentrations be-

cause of the little solubility of $\mathrm{O}_{3}$ in water. Such reaction is therefore enhanced during intense photochemical activity.

$\mathrm{HSO}_{3(\mathrm{aq})}^{-} \rightarrow \mathrm{H}_{(\mathrm{aq})}^{+}+\mathrm{SO}_{3(\mathrm{aq})}^{2-}$

$\mathrm{SO}_{3(\mathrm{aq})}^{2-}+\mathrm{O}_{3(\mathrm{aq})} \rightarrow \mathrm{O}_{2(\mathrm{aq})}+\mathrm{SO}_{4(\mathrm{aq})}^{2-}$

$\mathrm{SO}_{4(\mathrm{aq})}^{2-}+2 \mathrm{H}_{(\mathrm{aq})}^{+} \rightarrow \mathrm{H}_{2} \mathrm{SO}_{4(\mathrm{aq})}$

15 If the concentration of sulphate particles increases, it can enhance the nucleation and condensation processes. The redistribution of the industrial pollutants in a thin layer above and in the vicinity of the top of the gravity current can potentially increase the concentrations of secondary pollutants by intense photochemical activity during the day and contribute to the nucleation process of secondary organic aerosols (Song et al., 2005; $\mathrm{Ng}$ et al., 2007; Johnson et al., 2004; Johnson et al., 2005). The coastal air masses have turned, at the end of a sea-breeze day, into a stable horizontal multilayer structure, which was carried back inland by a rotation of the wind. Consequently, during night time, the detection of a multilayer structure observed by the lidar between 300

\section{Gaseous sulphur dioxide in a sea-breeze event}

C. Talbot et al.

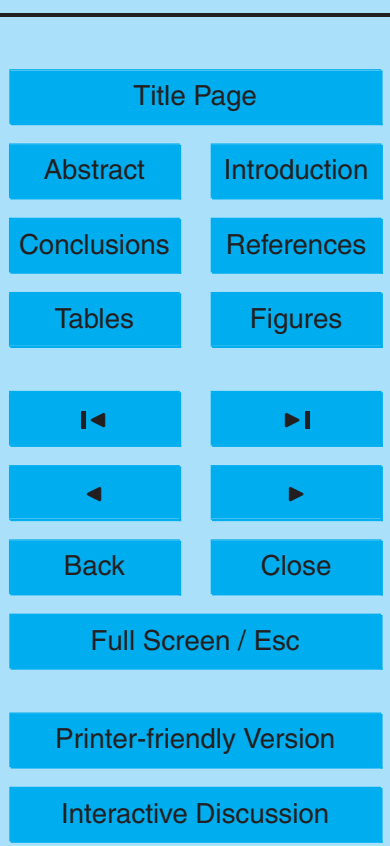


and $550 \mathrm{~m}$ (Fig. 8c) can be characterized by aerosols particles whose origins could be attributed to both industrial and urban local sources.

Near industrial coastal areas sea breezes can possibly generate acid clouds at the top of their sea-breeze front. A strong intensity of the sea-breeze gravity current en5 hances the vertical mixing in the sea-breeze front and favours the formation of seabreeze cumuli. Figure 10 represents the condensation in $\mathrm{g} / \mathrm{kg}$ of water (colour) at the top of the sea-breeze front on 15 September 2003 at 12:00 UTC. The isolines represent concentrations of the $\mathrm{SO}_{2}$ emitted from the industrial area during the day and the pollutant concentrations can be found at the top of the sea-breeze front, where a 10 sea-breeze cumulus is forming. The version of the model we used doesn't take into account heterogeneous chemical reactions and thus wet deposition. The condensation of water vapour originating from sea - land air dynamics can change the phase of the circulating chemical pollutants within the sea-breeze system and enhance the formation of (sulphuric) acid clouds in the vicinity of the sea-breeze front.

\section{Conclusions}

The structure of the lower troposphere during a sea-breeze event and its impact on the redistribution of the industrial $\mathrm{SO}_{2}$ emissions have been shown by combining numerical simulations and ground observations of active remote sensing instruments and meteorological and air quality monitoring stations. Vertical profiles produced by the simulations were compared to the lidar and the sodar vertical observations while horizontal computed fields at the ground level were correlated with the available ground measurements at the meteorological and the air quality monitoring stations.

It was shown that the TIBL trapped and mixed the pollutants emitted from the ground, while the gravity current transported this air mass inland, horizontally and close to the ground. Pollutants emitted before the sea-breeze onset were dispersed in the MBL. In the sea-breeze front, the pollutants emitted inside the sea breeze were swept away and blended by the vertical turbulence to the top of the sea-breeze front. Elevated

\section{Gaseous sulphur dioxide in a sea-breeze event \\ C. Talbot et al.}

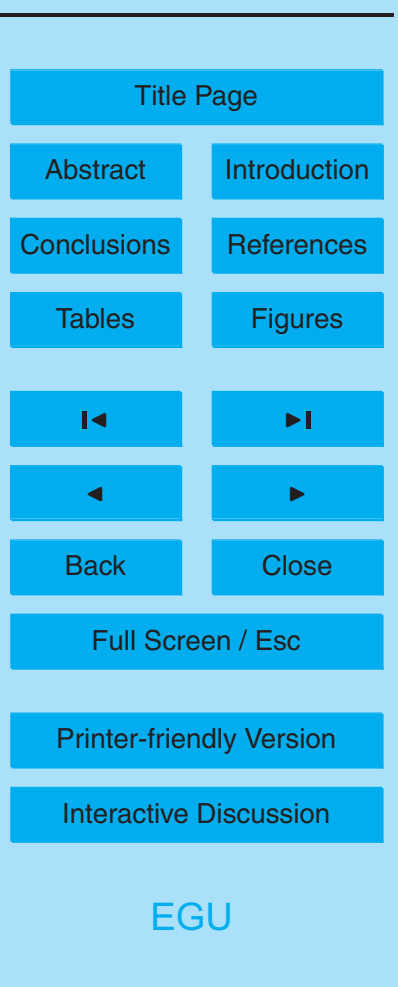


concentrations of pollutants were found in the headwind, which is characterized by a significantly subsiding offshore wind resulting from the synoptic wind and the seabreeze front, just behind the sea-breeze head. Redistribution of $\mathrm{SO}_{2}$ is shown by the model above the gravity current at the altitude of a High Reflectivity Layer (HRL). The 5 offshore synoptic flow carried the air masses swept upward by the front and blended it by shearing at the top of the HRL.

The polluted air mass located above the gravity current and the sea, which contained the pollutants emitted in the industrial area, can later generate a stable horizontal multilayered structure, as observed by the lidar and computed by the model.

10 Under intense sea-breeze conditions, the $\mathrm{SO}_{2}$ in industrial coastal areas is very likely to form acid aerosol particles by adiabatic cooling of the uplifted polluted layer. The sea-breeze front can be involved in the formation of acid clouds and the polluted layer can directly lower the $\mathrm{PH}$ of precipitations, leading to acid rain.

$\mathrm{SO}_{2}$ was used as a tracer in this study but is of course accompanied by a wide 15 variety of volatile organic compounds and aerosols. This study shows that the sea breeze occurrence leads to the formation of an elevated reservoir of pollutants relating to a regional scale larger than the sea-breeze dimensions. This reservoir is recycled the next day either in a new sea-breeze system or in the atmospheric boundary layer outside the sea-breeze system, and will thus add to the fresh pollutants and participate in the next day's photochemistry. By keeping the pollutants close to their emission point at a regional scale, a succession of breeze days can then lead to an amplification of the background regional air pollution.

Acknowledgements. We thank IDRIS for their computation facilities under project \#071737. We are thankful to C. Mari and J. Escobar (Laboratoire d'Aérologie, CNRS) and P.Tulet (C.N.R.M.) 25 for their assistance in setting up the model and their helpful experience. Thanks to $C$. Beaugard and $\mathrm{H}$. Cherigui for the work they carried out (ATMO Nord Pas-de-Calais), and ATMO Nord Pas-de-Calais and Météo-France for their observed data and archive data from the ARPEGE model. Thanks to the European Center for Medium-range Weather Forecasts for the reanalysis data of the MARS model. The LPCA and ELICO laboratories participate in the Institut de 30 Recherches en ENvironnement Industriel (IRENI) which is financed by the Region Nord-Pas16006

\section{Gaseous sulphur dioxide in a sea-breeze event \\ C. Talbot et al.}

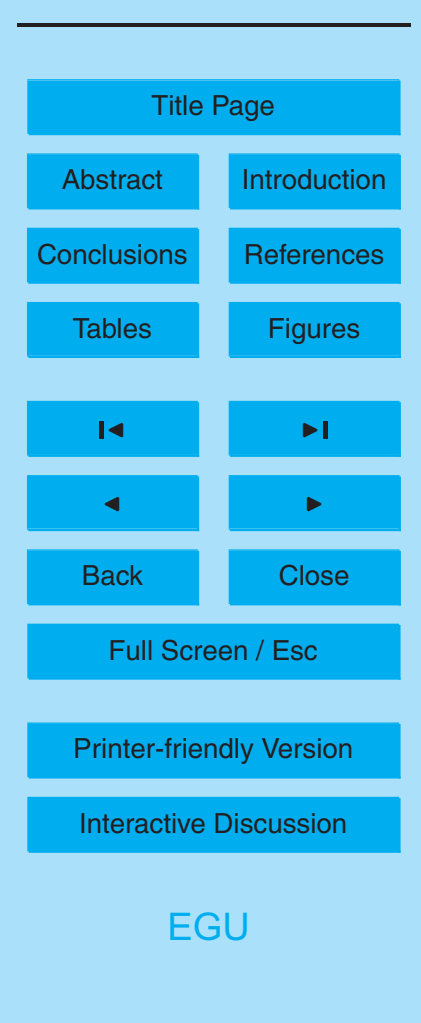


de-Calais, the Ministère de la Recherche and European funds (FEDER). C. Talbot thanks the Agence Nationale de la Recherche Technique, ACRI-ST and ATMO Nord Pas de Calais for their financial supports.

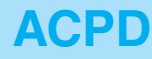

7, 15989-16022, 2007

\section{References}

5 Abbs, D. J.: Sea breeze interactions along a concave coastline in southern Australia: observations and numerical modeling study, Mon. Weather Rev., 114, 831-848, 1986.

Augustin, P., Delbarre, H., Lohou, F., Campistron, B., Puygrenier, V., Cachier, H., and Lombardo, T.: Investigation of local meteorological events and their relationship with ozone and aerosols during an ESCOMPTE photochemical episode, Ann. Geophys., 24, 2809-2822, 2006 ,

http://www.ann-geophys.net/24/2809/2006/.

Badol, C., Locoge, N., and Gallo, J. C.: Using a source-receptor approach to characterize VOC behaviour in a French urban area influenced by industrial emissions. Part II : Qualitative data analysis in the way to show the influence of multiple sources on VOC ambient concentrations,

15 Sci. Total Environ., in press, 2007.

Boone, A., Calvet, J. C., and Noilhan, J.: Inclusion of a third soil layer in a land-surface scheme using the force-restore method, J. Appl. Meteorol., 38, 1611-1630, 1999.

Bougeault, P. and Lacarrere, P.: Parametrization of orography induced turbulence in a mesobeta-scale model, Mon. Weather Rev., 117, 1872-1890, 1989.

Calvet, J. C., Noilhan, J., Roujean, J. L., Bessemoulin, P., Cabelguenne, M., Olioso, A., and Wigneron, J. P.: An interactive vegetation SVAT model tested against data from six contrasting sites, Agr. Forest Meteorol., 92, 73-95, 1998.

Charnock, H.: Wind stress on a water surface, Q. J. Roy. Meteor. Soc., 81, 639-640, 1955.

Chen, W., Kuze, H., Uchiyama, A., Suzuki, Y., and Takeuchi, N.: One-year observation of urban mixed layer characteristics at Tsukuba, Japan using a micro pulse lidar, Atmos. Environ., 35, 4273-4280, 2001.

Coulter, R. L.: A case study of turbulence in the stable nocturnal boundary layer, Bound.-Lay. Meteorol., 52, 75-91, 1990.

Crassier, V., Suhre, K., Tulet, P., and Rosset, R.: Development of a reduced chemical scheme for use in mesoscale meteorological models, Atmos. Environ., 34, 2633-2644, 2000.

\section{Gaseous sulphur dioxide in a sea-breeze event}

C. Talbot et al.

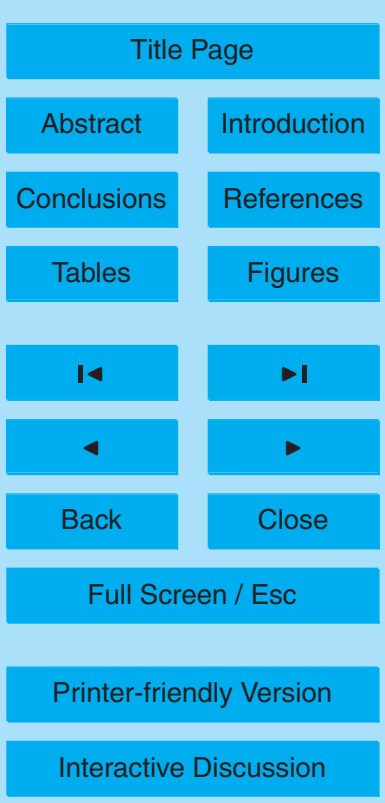


Cuxart, J., Bougeault, P., and Redelsperger, J. L.: A turbulence scheme allowing for mesoscale and large-eddy simulations, Q. J. Roy. Meteor. Soc., 126, 1-30, 2000.

Deardorff, J. W.: Numerical investigation of neutral and unstable planetary boundary layers, J. Atmos. Sci., 29, 91-115. 1972.

5 Déqué, M., Drevton, A., Braun, A., and Cariolle, D.: The ARPEGE/IFS atmosphere model: A contribution to the French community climate modelling, Clim. Dynam., 10, 249-266, 1994.

DRIRE: "L'Industrie au Regard de l'environnement en 2000", Direction Régionale de l'Industrie, de la Recherche et de l'Environnement du Nord Pas de Calais, 2001.

Durand, P., Briere, S., and Druilhet, A.: A sea-land transition observed during the coast experiment, J. Atmos. Sci., 46, 96-116, 1989.

Garratt, J. R.: The Internal Boundary-Layer - A review, Bound.-Lay. Meteorol., 50, 171-203, 1990.

Gilliam, R. C., Raman S., and Niyogi Dev dutta, S.: Observational and numerical study on the influence of large-scale flow direction and coastline shape on sea-breeze evolution, Bound.Lay. Meteorol., 111, 275-300, 2004.

Hains, J. C.: A chemical climatology of lower tropospheric trace gases and aerosols over the mid-Atlantic region, thesis, Department of atmospheric and oceanic sciences, University du Maryland, USA, 2007.

Harris, L. and Kotamarthi, V. R.: The characteristics of the Chicago Lake breeze and its effects on trace particle transport: Results from an episodic event simulation, J. Appl. Meteorol., 44, 1637-1654, 2005.

Hewitt, C. N.: The atmospheric chemistry of sulphur and nitrogen in power station plumes, Atmos. Environ., 35, 1155-1170, 2001.

Holton, J. R.: An Introduction to Dynamic Meteorology, International Geophysics Series, 48, Academic Press, Third edition, London, UK, 511 pp., 1992.

Howell, J. F. and Sun, J.: Surface-Layer Fluxes in stable conditions, Bound.-Lay. Meteorol., 90, 495-520, 1999.

Jacobson, M. Z.: Atmospheric pollution: History, Science, and Regulation, Cambridge University Press, 399 pp., 2002.

so Johnson, D., Jenkin, M. E., Wirtz, K., and Martin-Reviejo, M.: Simulating the formation of secondary organic aerosol from the photooxidation of toluene, Environ. Chem., 1, 150-165, 2004.

Johnson, D., Jenkin, M. E., Wirtz, K., and Martin-Reviejo, M.: Simulating the formation of sec-

\section{Gaseous sulphur dioxide in a sea-breeze event}

C. Talbot et al.

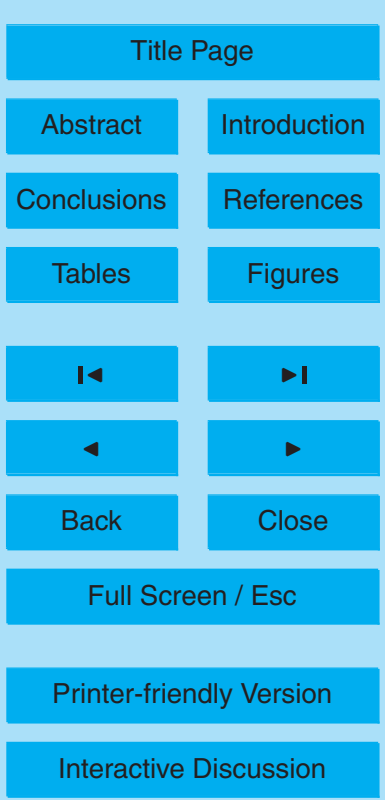

EGU 
ondary organic aerosol from the phootoxidation of aromatic hydrocarbons, Environ. Chem., 2, 35-48, 2005.

Khoder, M. I.: Atmospheric conversion of sulfur dioxide to particulate sulfate and nitrogen dioxide to particulate nitrate and gaseous nitric acid in an urban area, Chemosphere, 49, 675$5684,2002$.

Kouchi, A., Ohba, R., and Shao, Y.: Gas diffusion in a convection layer near a coastal region, J. Wind Eng. Ind. Aerod., 81, 171-180, 1999.

Lafore, J. P., Stein, J., Asencio, N., Bougeault, P., Ducrocq, V., Duron, J., Fischer, C., Héreil, P., Mascart, P., Masson, V., Pinty, J. P., Redelsperger, J. L., Richard, E., and Vilà-Guerau de Arellano, J.: The Meso-NH Atmospheric Simulation System. Part I: Adiabatic formulation and control simulations, Ann. Geophys., 16, 90-109, 1998,

http://www.ann-geophys. net/16/90/1998/.

Ledoux, F.: Les aérosols particulaires atmosphériques sur le Dunkerquois: caractérisations chimiques, physiques, spectroscopiques et évaluation de leur toxicité, Ph.D. Thesis, Univer-

15 sity of Littoral Côte d'Opale, Dunkerque, France, 2003.

Luhar, A. K., Sawford, B. L., Hacker, J. M., and Rayner, K. N.: The Kwinana coastal fumigation study: 2 - Growth of the thermal internal boundary layer, Bound.-Lay. Meteorol., 89, 385405, 1998.

Mahrt, L., Sun, J., Blumen, W., Delany, T., and Oncley, S.: Nocturnal Boundary-Layer Regimes, 20 Bound.-Lay. Meteorol., 88, 255-278, 1998a.

Mahrt, L.: Stratified Atmospheric Boundary Layers, Bound.-Lay. Meteorol., 90, 375-396, 1999.

Mari, C., Jacob, D. J., and Bechtold, P.: Transport and scavenging of soluble gases in a deep convective cloud, J. Geophys. Res., 105, 22 255-22 263, 2000.

Masson, V.: A physically-based scheme for the urban energy budget in atmospheric models,

25 Bound.-Lay. Meteorol., 94, 357-397, 2000.

Marti, J. J., Jefferson, A., Cai, X. P., Richert, C., McHurry, P. H., and Eisele, F.: $\mathrm{H}_{2} \mathrm{SO}_{4}$ vapor pressure of sulfuric acid and ammonium sulfate solutions, J. Geophys. Res., 102, 37253735, 1997.

Menut, L., Flamant, C., Pelon, J., and Flamant, P. H.: Urban boundary-layer height determina-

30 tion from lidar measurements over the Paris area, Appl. Optics, 38, 945-954, 1999.

Miller, S. T. K., Keim, B. D., Talbot, R. W., and Mao, H.: The sea-breeze: Structure, forecasting, and impacts, Rev. Geophys., 41, 1011, doi:10.1029/2003RG000124, 2003.

Morcrette, J. J.: Radiation and cloud radiative properties in the European center for medium

\section{Gaseous sulphur dioxide in a sea-breeze event}

C. Talbot et al.

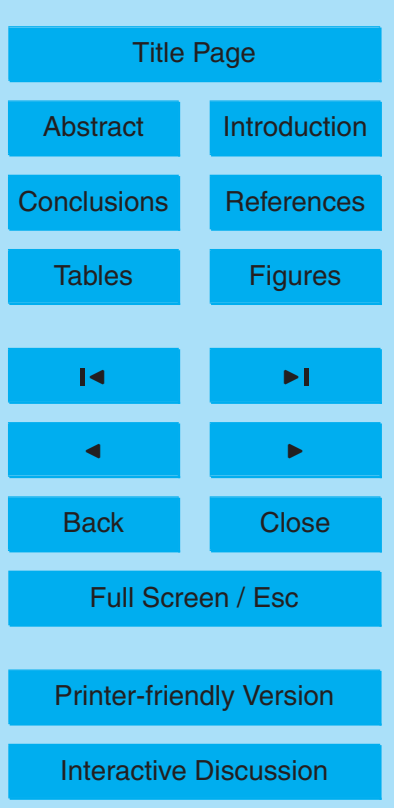

EGU 
range weather forecasts forecasting system, J. Geophys. Res., 96, 9121-9132, 1991.

Nazir, M., Khan, F. I., and Husain, T.: Revised estimates for continuous shoreline fumigation: a PDF approach, J. Hazard. Mater., A 118, 53-65, 2005.

Ng, N. L., Kroll, J. H, Chan, A. W. H., Chhabra, P. S., Flagan, R. C., and Seinfeld, J. H.:

5 Secondary organic aerosol formation from $\mathrm{m}$-xylene, toluene, and benzene, Atmos. Chem. Phys., 7, 3909-3922, 2007,

http://www.atmos-chem-phys.net/7/3909/2007/.

Noilhan, J. and Planton, S.: A simple parameterization of land surface processes for meteorological models, Mon. Weather Rev., 117, 536-549, 1989

10 Noilhan, J. and Mahfouf, J. F.: The ISBA land surface parametrization scheme, Global Planet. Change, 13, 145-159, 1996.

Notholt, J., Luo, B. P., Fueglistaler, S., Weisenstein, D., Rex, M., Lawrence, M. G., Bingemer, H., Wohltmann I., Corti, T., Warneke, T., Von Kuhlmann, R., and Peter, T.: Influence of tropospheric $\mathrm{SO}_{2}$ emissions on particle formation and the stratospheric humidity, Geophys. Res. Lett., 32(7), L07810, doi:10.1029/2004GL022159, 2005.

Ohba, R., Shao, Y., and Kouchi, A.: A wind tunnel and numerical investigation of turbulent dispersion in coastal atmospheric boundary layers, Bound.-Lay. Meteorol., 87, 255-273, 1998.

Physick, W. L.: Numerical experiments on the inland penetration of the sea breeze, Q. J. Roy. Meteor. Soc., 106, 735-746, 1980.

Poulos, G. S., Blumen, W., Fritts, D. C., Lundquist, J. K., Sun, J., Burns, S. P., Nappo, C., Banta, R., Newsom, R., Cuxart, J., Terradellas, E., Balsley, B., and Jensen, M.: CASES-99: A comprehensive investigation of the stable nocturnal boundary layer, B. Am. Meteorol. Soc., 83, 555-581, 2002.

Salmond, J. A.: Wavelet analysis of intermittent turbulence in a very stable nocturnal boundary layer: implications for the vertical mixing of ozone, Bound.-Lay. Meteorol., 114, 463-488, 2005.

Seinfeld, J. H. and Pandis, S. N.: Atmospheric Chemistry and Physics: from air pollution to climate change, Wiley-Interscience, 1326 pp., 1998.

30 Simpson, J. E.: Notes and correspondence: diurnal changes in sea-breeze direction, J. Appl. Meteorol., 35, 1166-1169, 1995.

Song, C., Na, K., and Cocker, D. R.: Impact of the hydrocarbon to NOx ratio on secondary organic aerosol formation, Environ. Sci. Technol., 39, 3143-3149, 2005.

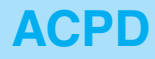

7, 15989-16022, 2007

\section{Gaseous sulphur dioxide in a sea-breeze event}

C. Talbot et al.

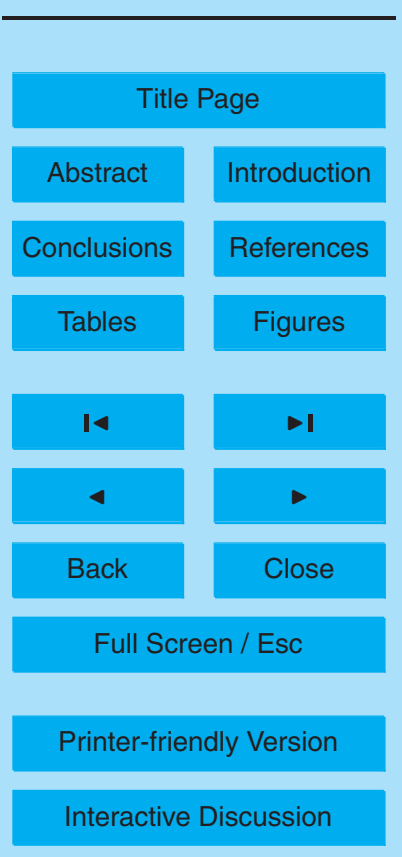


Srinivas, C. V. and Venkatesan, R.: A simulation study of dispersion of air borne radionuclides from a nuclear power plant under a hypothetical accidental scenario at a tropical coastal site, Atmos. Environ., 39, 1497-1511, 2005.

Steyn, D. G.: Scaling the vertical structure of sea-breezes, Bound.-Lay. Meteorol., 86, 505-524, 1998.

Stockwell, R. W., Kirchner, F., Kuhn, M., and Seefeld, S.: A new mechanism for regional atmospheric chemistry modelling, J. Geophys. Res., 102, 25 847-25 879, 1997.

Stull, R. B.: An Introduction to Boundary Layer Meteorology, Kluwer Academic Publishers, Dordrecht, The Netherlands, 666 pp., 1988.

10 Talbot, C., Augustin, P., Leroy, C., Willart, V., Delbarre, H., and Khomenko, G.: Impact of a sea breeze on the boundary-layer dynamics and the atmospheric stratification in a coastal area of the North Sea, Bound.-Lay. Meteorol., 133-154, doi:10.1007/s10546-007-9185-6, 2007.

Tulet, P., Crassier, V., and Rosset, R.: Air pollution modelling at a regional scale, Environ. Modell. Softw., 15, 693-701, 2000.

Tulet, P., Crassier, V., Solmon, F., Guedalia, D., and Rosset, R.: Description of the Mesoscale Non Hydrostatic Chemistry model and application to a transboundary pollution episode between northern France and southern England, J. Geophys. Res., 108(D1), 1-11, doi.10.1029/2000JD000301, 2003.

Venkatram, A.: An examination of methods to estimate the height of the coastal internal boundary layer, Bound.-Lay. Meteorol., 36, 149-156, 1986.

Weber, A. H. and Kurzeja, R. J.: Nocturnal planetary boundary-layer structure and turbulence episodes during the project stable field program, J. Appl. Meteorol., 30, 1117-1133, 1991.

Wesely, M. L.: Parameterization of surface resistance to gaseous dry deposition in regional numerical models. Atmos. Environ., 16, 1293-1304, 1989.

Whelpdale, D. M. and Miller, J. W.: GAW and precipitation chemistry measurement activities, Fact Sheet Number 5, Background Air Pollution Monitoring Program, World Meteorological Organization, Geneva, Switzerland, 1989.

Yuan J., Venkatram, A., and Isakov, V.: Dispersion from ground-level sources in a shoreline urban area, Atmos. Environ., 40, 1361-1372, 2005.

\section{Gaseous sulphur dioxide in a sea-breeze event}

C. Talbot et al.

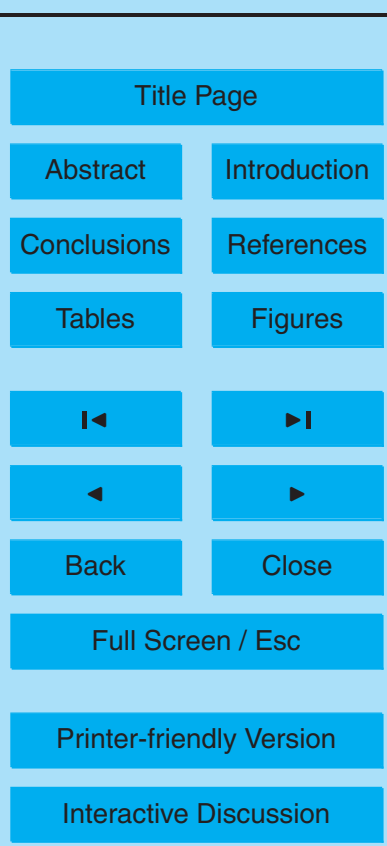




\section{ACPD}

7, 15989-16022, 2007

\section{Gaseous sulphur} dioxide in a sea-breeze event

C. Talbot et al.

Table 1. Classification of the air quality monitoring stations according to the French Agency for Environment and Energy Management.

\begin{tabular}{llll}
\hline Station & Category & Station & Category \\
\hline DK2 & traffic & DK8 & urban \\
DK3 & industrial & DKB & urban \\
DK5 & industrial & DKC & industrial \\
DK7 & industrial & DKD & industrial \\
\hline
\end{tabular}

Title Page

Abstract

Conclusions

Tables

14

4

Back

Full Screen / Esc

Printer-friendly Version

Interactive Discussion 


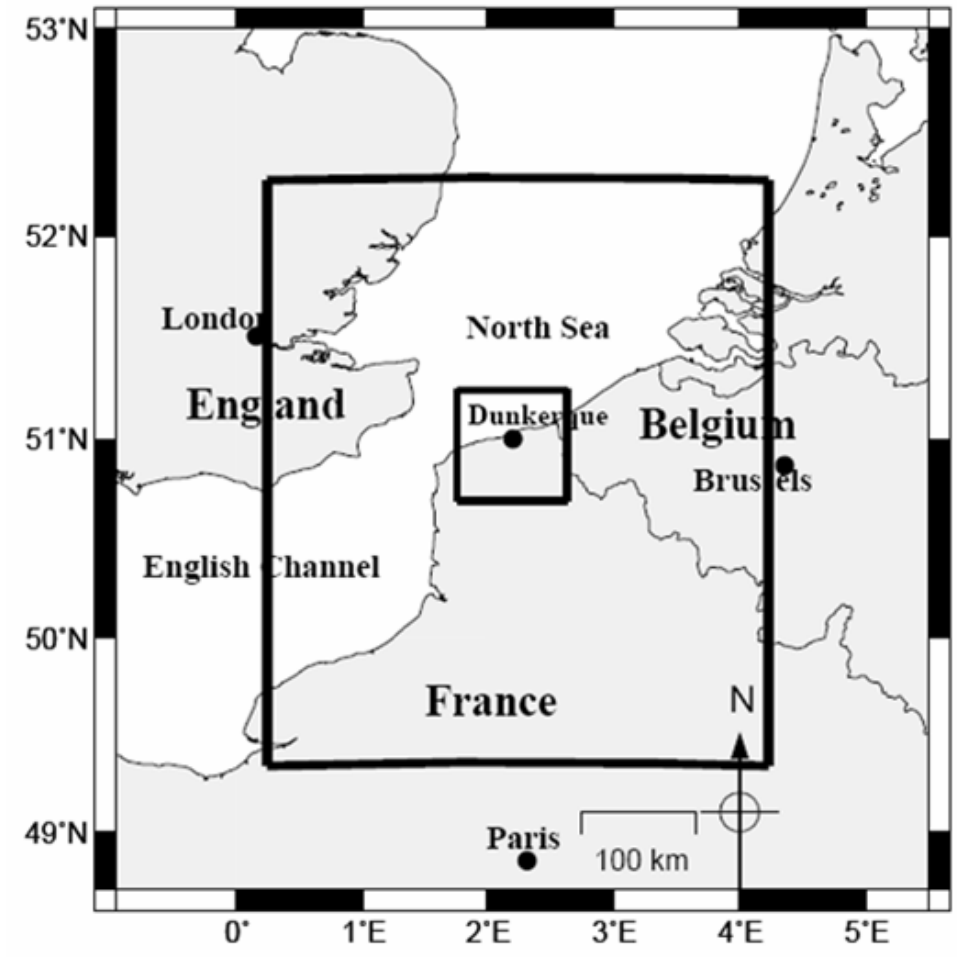

Fig. 1. Geographical position of the studied area. The two Meso-NH-C nested models used for the numerical simulation are represented by the two black contours. The 5-km lower horizontal resolution model covers the South-East of England, North of France and part of Belgium. The 1-km higher horizontal resolution model covers the Dunkerque area.

\section{7, 15989-16022, 2007}

\section{Gaseous sulphur} dioxide in a sea-breeze event

C. Talbot et al.

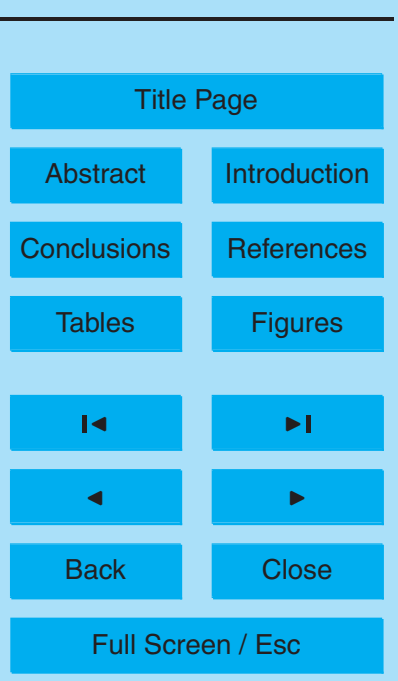

Printer-friendly Version

Interactive Discussion 


\section{ACPD}

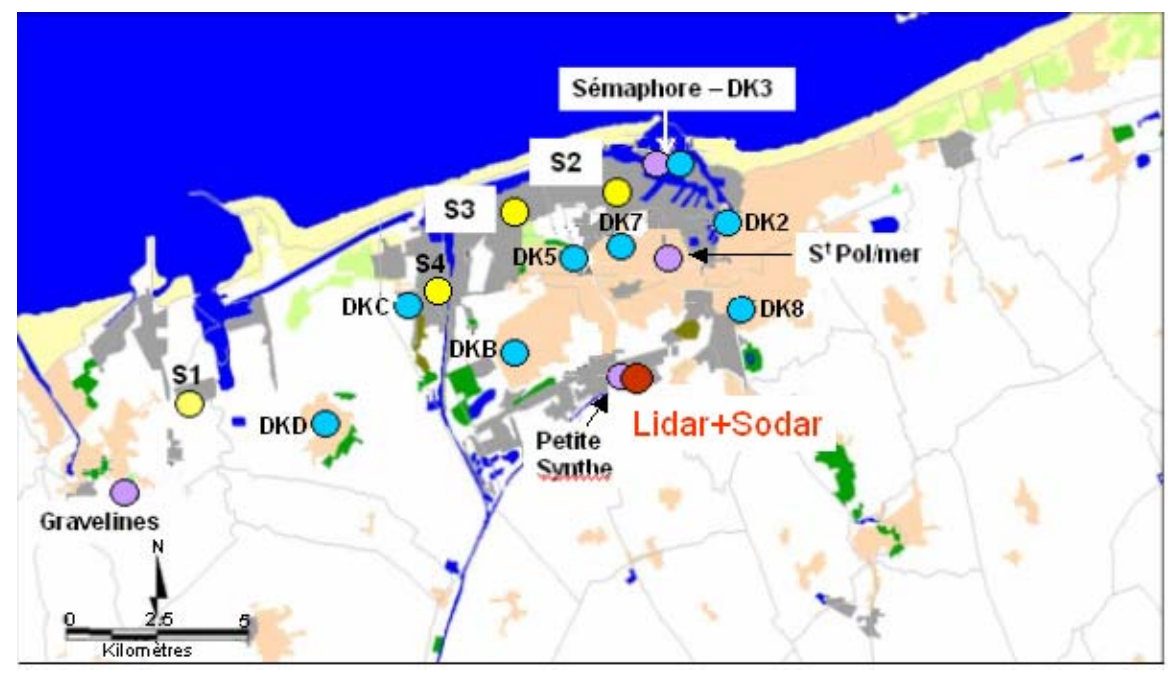

Fig. 2. Position of the lidar and sodar instruments (red dot) and location of the ATMO Nord Pas-de-Calais and Météo-France ground stations in the Dunkerque area: the meteorological stations are represented by violet dots and the stations measuring the pollutant concentrations by blue dots. The yellow dots highlight the major sources of emitted $\mathrm{SO}_{2}$.

\section{Gaseous sulphur dioxide in a sea-breeze event \\ C. Talbot et al.}

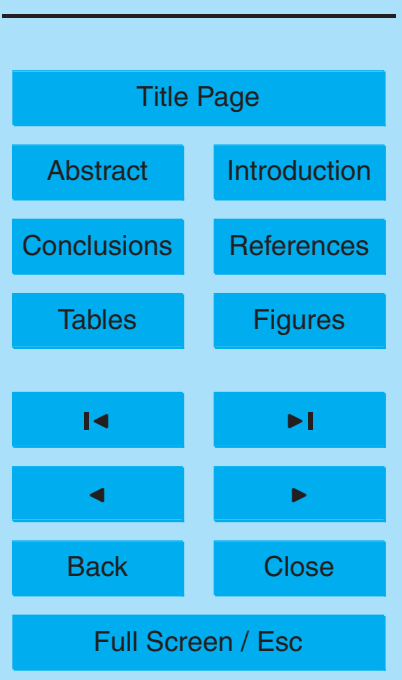

Printer-friendly Version

Interactive Discussion 


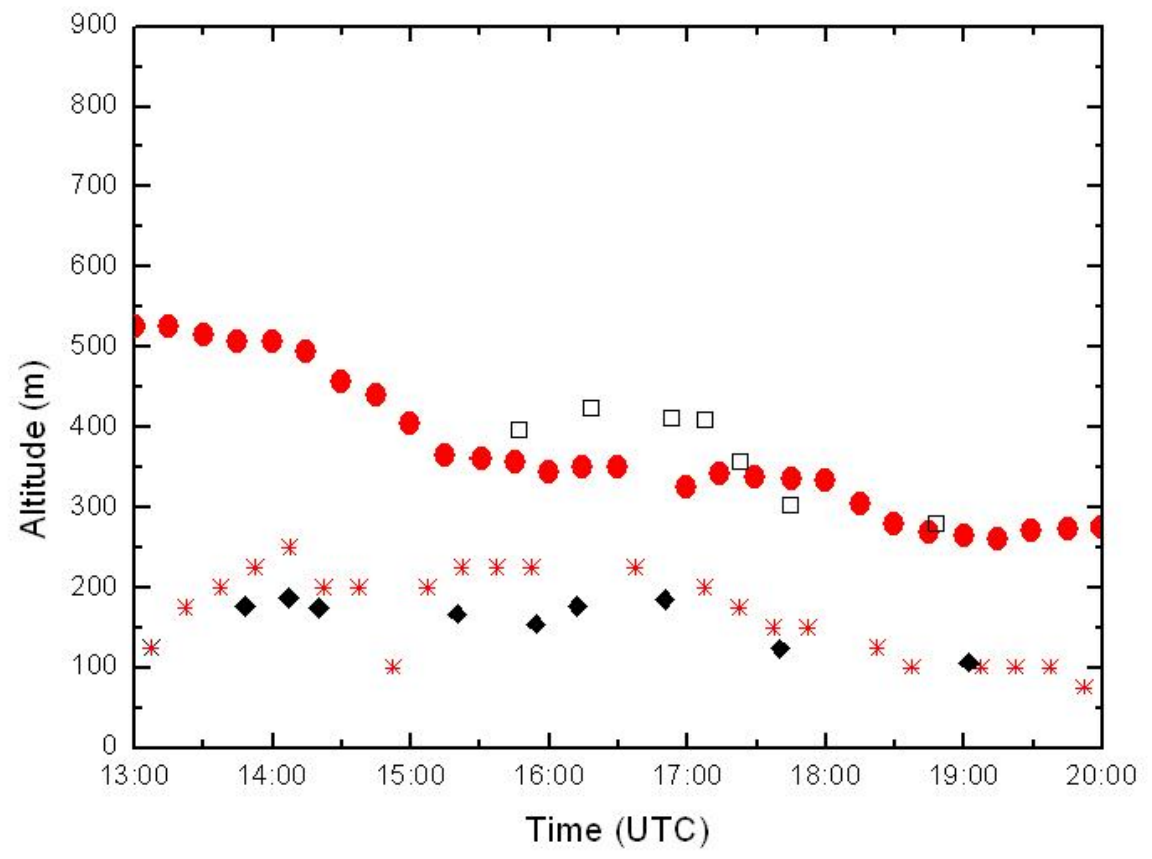

Fig. 3. Sea-breeze structure at Petite-Synthe deduced from the lidar measurements with the IPM method (black diamonds: thermal internal boundary-layer top, white rectangles: top of the highly reflective layer (HRL) and from the sodar measurements, red circles: sea-breeze gravity current top, red asterisks: local decreasing of the vertical velocity variance $\sigma_{w}^{2}$ at the top of the thermal internal boundary-layer).

\section{ACPD}

7, 15989-16022, 2007

\section{Gaseous sulphur dioxide in a sea-breeze event \\ C. Talbot et al.}

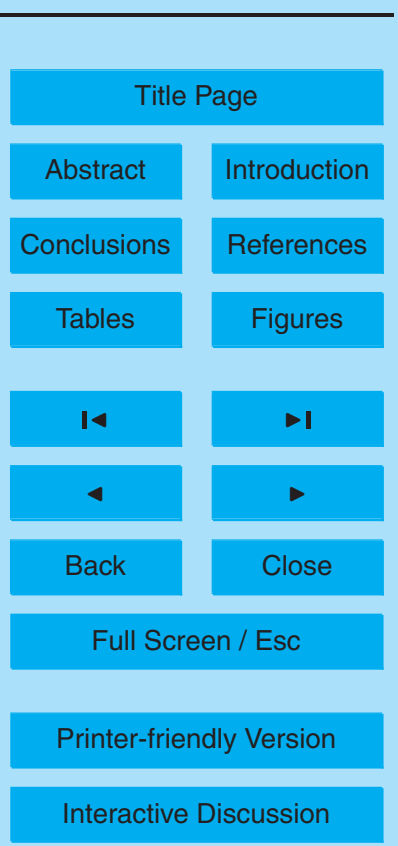




\section{ACPD}
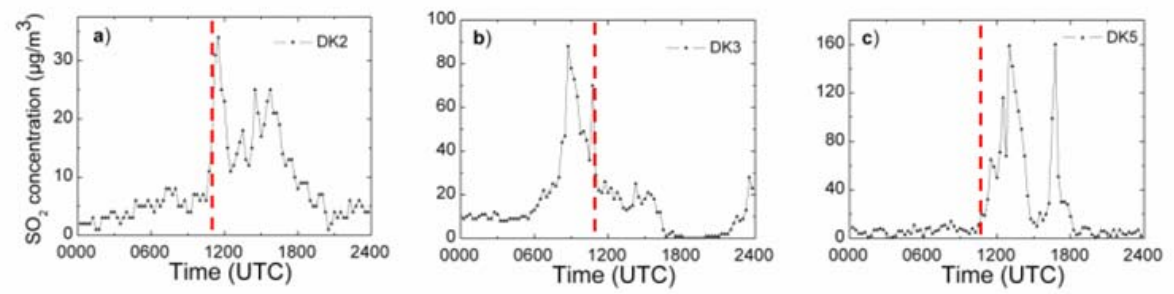

\section{7, 15989-16022, 2007}
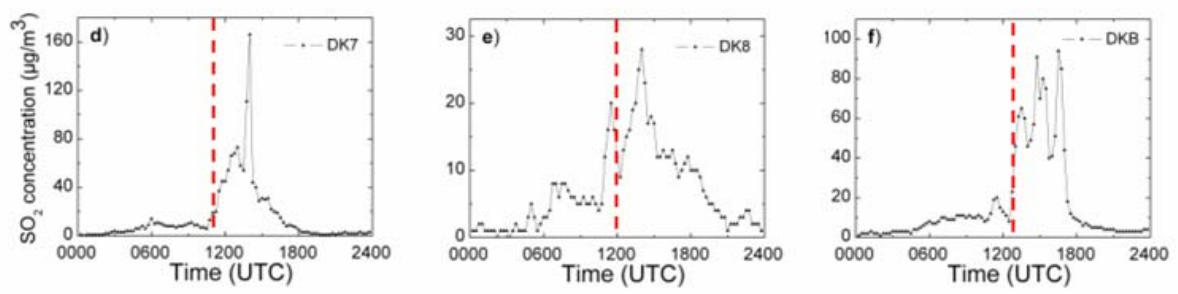

\section{Gaseous sulphur dioxide in a sea-breeze event}

C. Talbot et al.
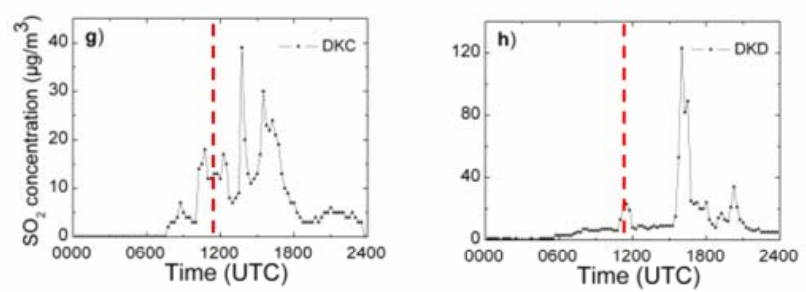

Fig. 4. Temporal evolution of the $\mathrm{SO}_{2}$ concentration measured at the air quality monitoring stations on 15 September 2003. Dashed lines indicate the passage of the sea-breeze front above each station.

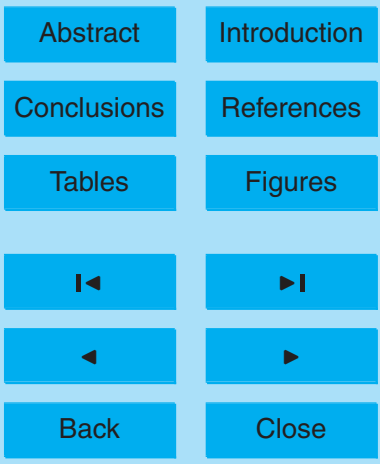

Full Screen / Esc

Printer-friendly Version

Interactive Discussion 


\section{ACPD}

7, 15989-16022, 2007

\section{Gaseous sulphur dioxide in a \\ sea-breeze event}

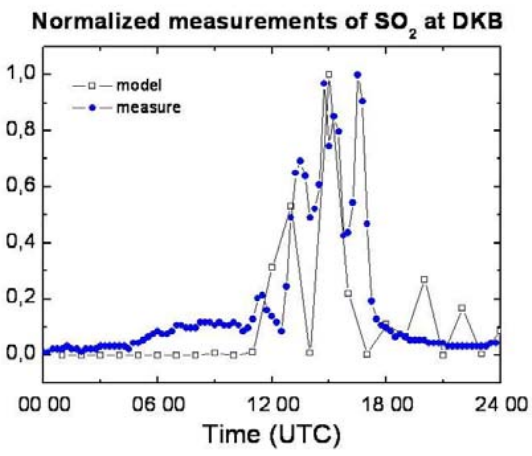

(a)

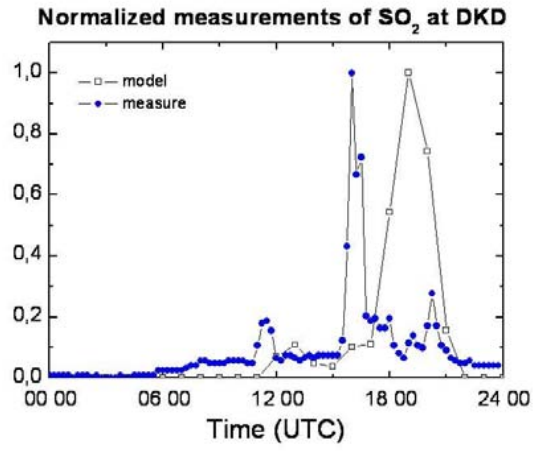

(b)

Fig. 5. Observed and computed evolution of the normalized $\mathrm{SO}_{2}$ concentration at (a) DKB station and (b) DKD station.

C. Talbot et al.

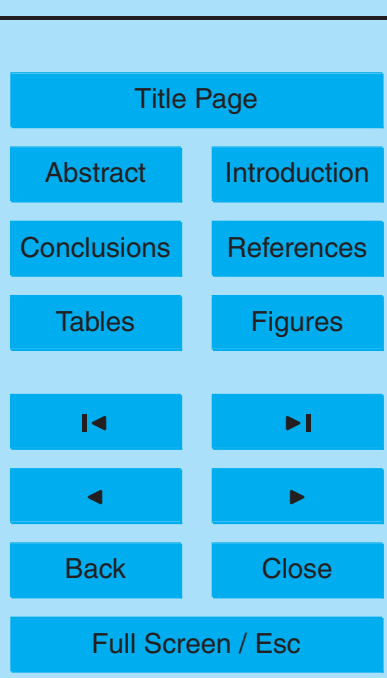

Printer-friendly Version

Interactive Discussion 


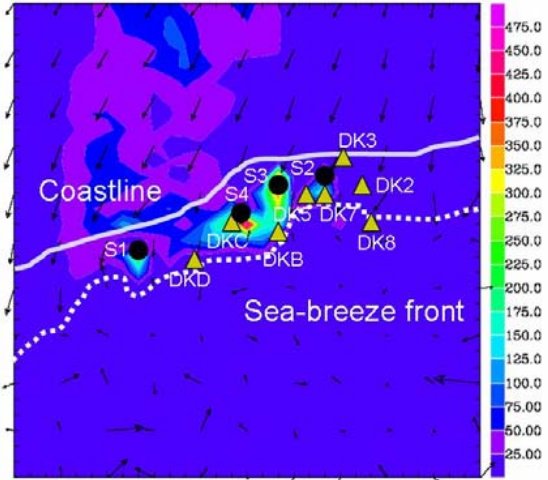

(a)

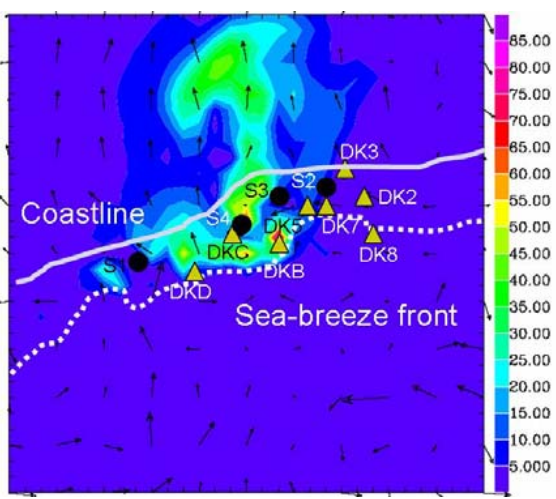

(b)

Fig. 6. Horizontal cross section at $1200 \mathrm{UTC}$ of the industrial $\mathrm{SO}_{2}$ concentration in ppbv (colour scale) and horizontal wind velocity (arrows) simulated by the model (a) at $10 \mathrm{~m}$ above ground level (a.g.l.) and (b) at $350 \mathrm{~m}$ a.g.I. Stations are represented by triangles, the four main sources of $\mathrm{SO}_{2}$ by black dots. The position of the sea-breeze front is represented by the dashed white line and the coastline by the plain white line. The west-east distance along the abscissa axis is $60 \mathrm{~km}$.

\section{Gaseous sulphur} dioxide in a sea-breeze event

C. Talbot et al.

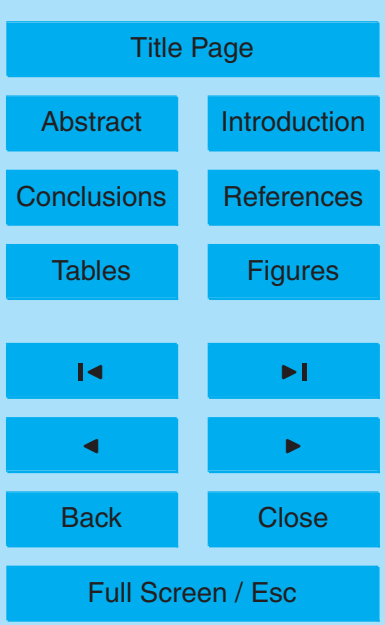

Printer-friendly Version

Interactive Discussion 


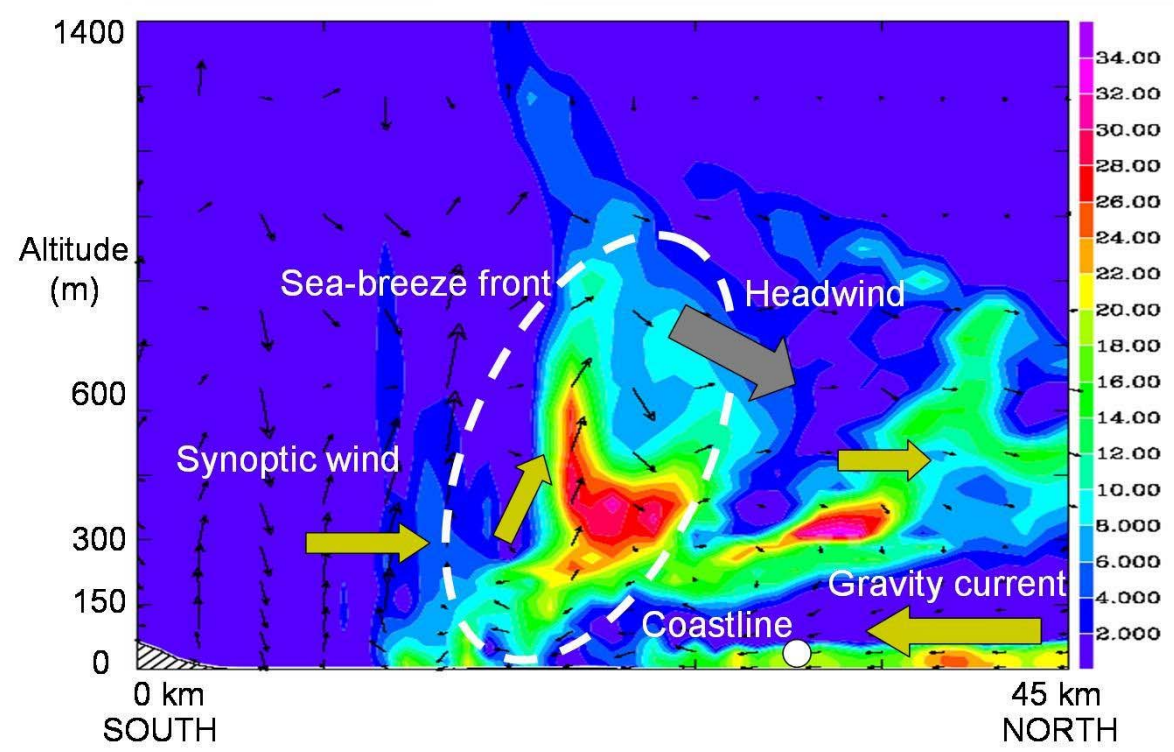

Fig. 7. North-south vertical cross section of industrial $\mathrm{SO}_{2}$ concentrations in ppbv (colour scale) simulated by the model, with the wind velocity in the cross section (vectors) at 14:00 UTC. The south-north distance along the abscissa axis is $45 \mathrm{~km}$. The coastline is represented by the white dot.
ACPD

7, 15989-16022, 2007

Gaseous sulphur dioxide in a sea-breeze event

C. Talbot et al.

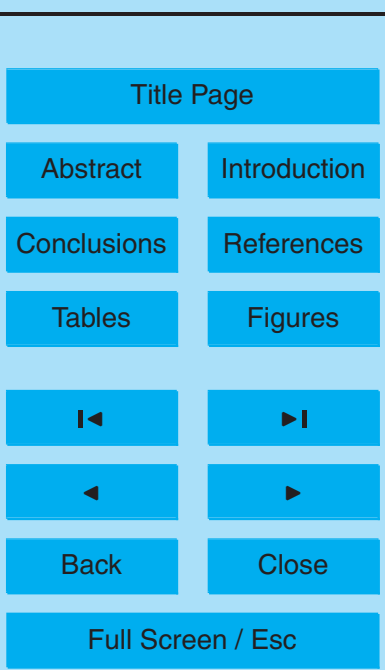

Printer-friendly Version

Interactive Discussion 


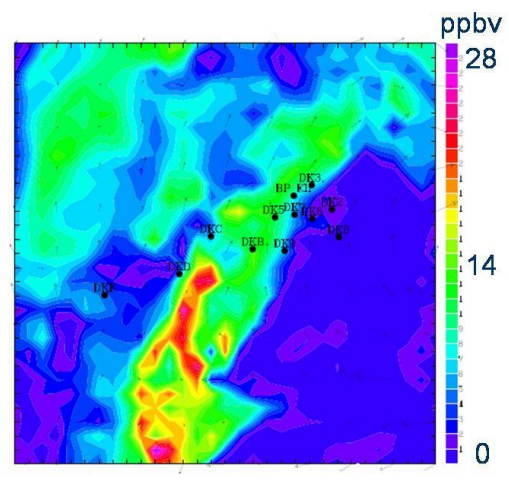

(a)

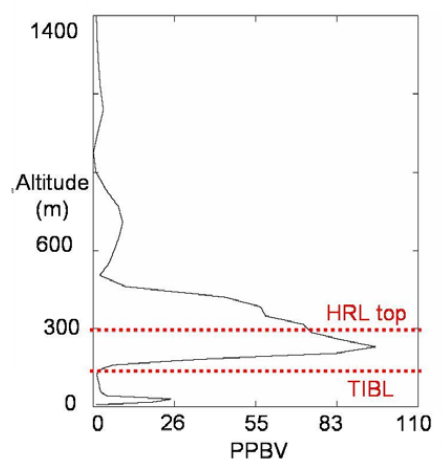

(b)

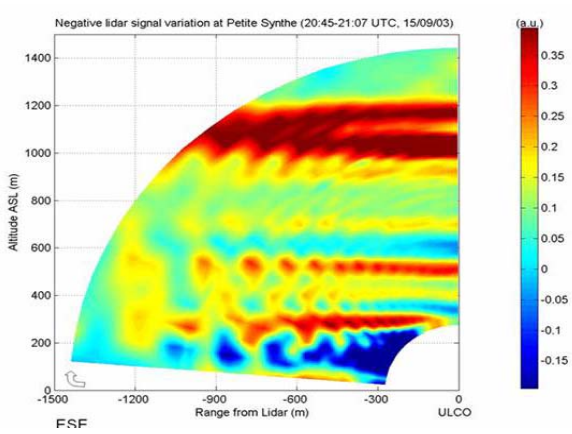

(c)

Fig. 8. Redistribution of the pollutants above the areas of emission, at low altitude. (a) Horizontal Meso-NH-C cross section of $\mathrm{SO}_{2}$ concentrations at $350 \mathrm{~m}$ above ground level at 17:00 UTC. (b) Computed profile of $\mathrm{SO}_{2}$ concentrations above the DKB station at 18:00 UTC, with respective transition zones detected by Inflexion Point Method: tops of the high reflectivity layer at $300 \mathrm{~m}$ and the thermal internal boundary layer at $150 \mathrm{~m}$. (c) Lidar scan of the lower troposphere at 21:00 UTC: a multilayered structure is detected to $600 \mathrm{~m}$.

\section{ACPD}

7, 15989-16022, 2007

\section{Gaseous sulphur dioxide in a sea-breeze event}

C. Talbot et al.

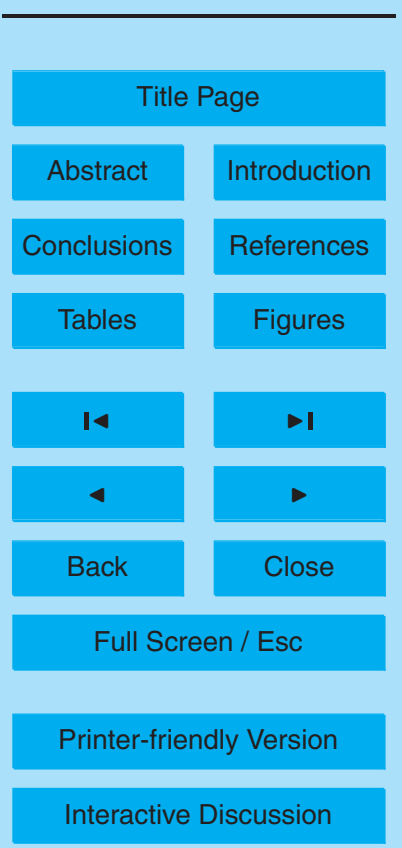




\section{ACPD}

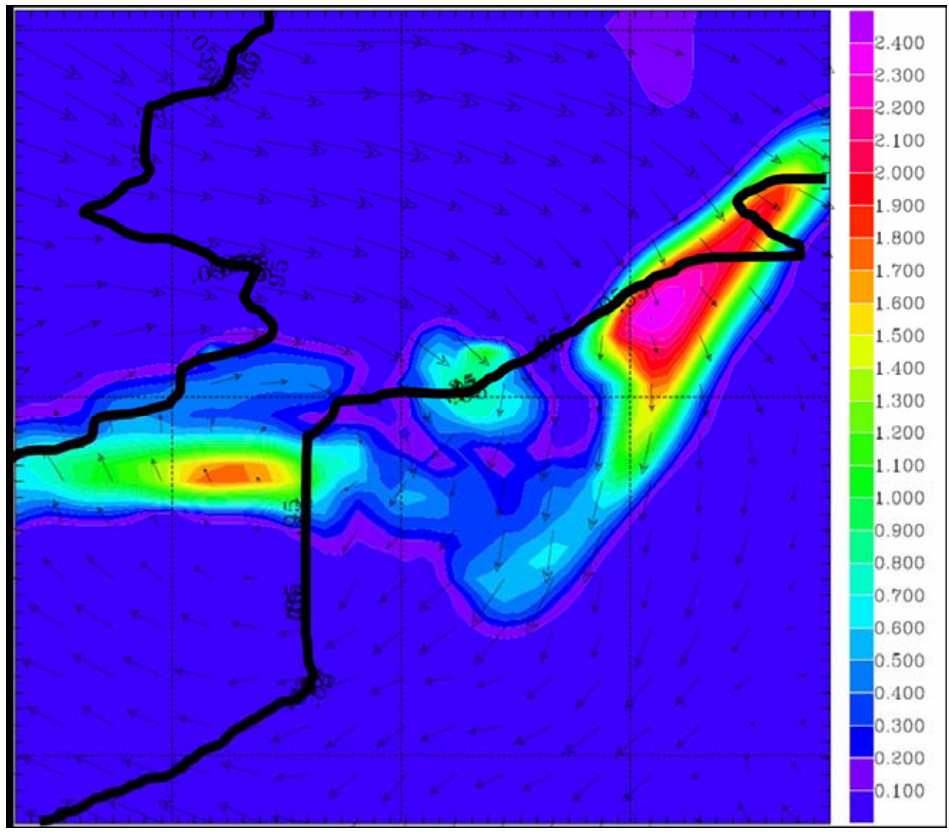

\section{Gaseous sulphur}

dioxide in a sea-breeze event

C. Talbot et al.

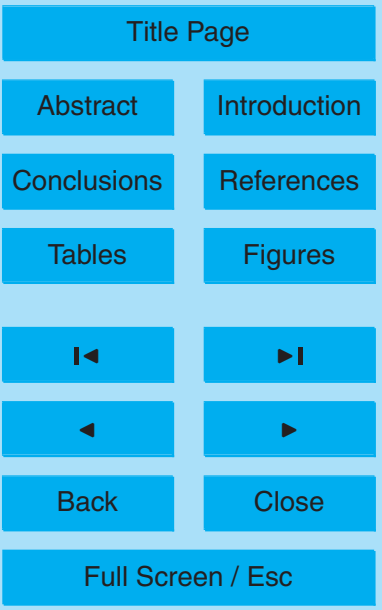

Fig. 9. Horizontal cross section of the $\mathrm{SO}_{2}$ concentration in ppbv (colour scale) and the wind velocity (black arrows) at 06:00 UTC on 16 September at $300 \mathrm{~m}$. The black lines represent the coastlines of the English Channel and the North Sea.

Printer-friendly Version

Interactive Discussion 


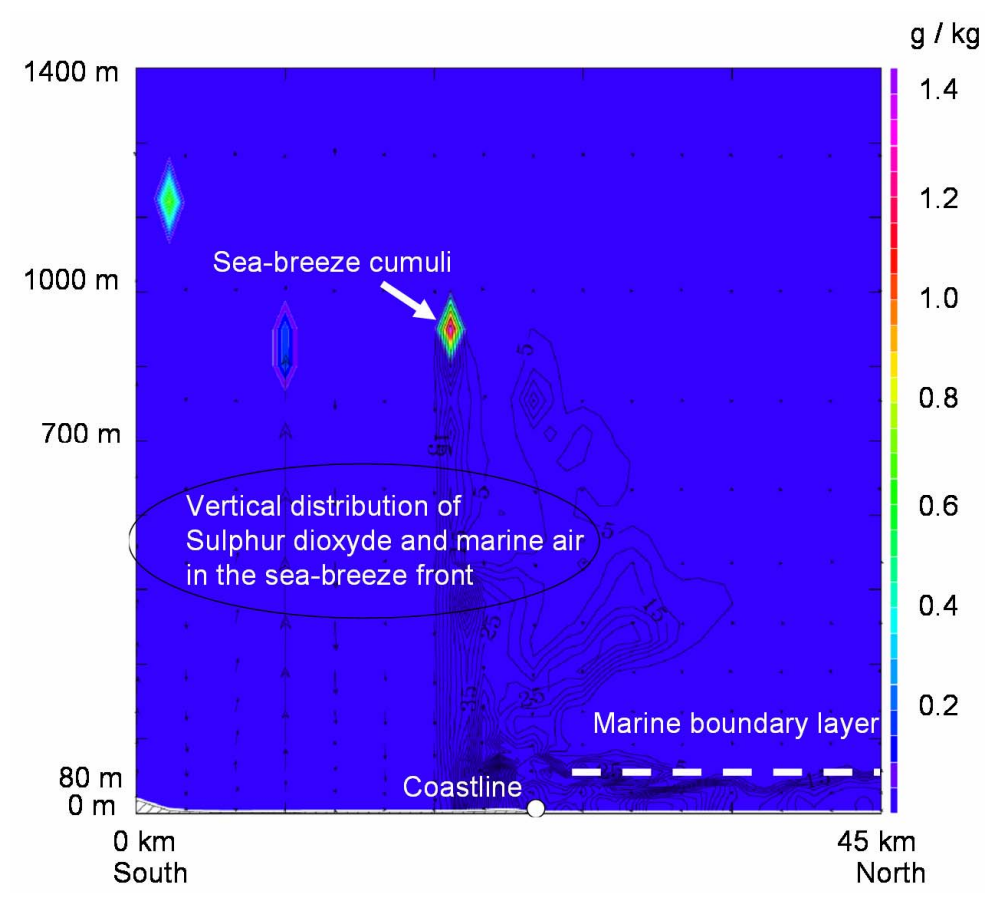

Fig. 10. $45 \mathrm{~km}$ of vertical south-north cross section computed by the model, at 12:00 UTC and from 0 to $1400 \mathrm{~m}$, of the condensed water in $\mathrm{g} / \mathrm{kg}$ (colours), with the $\mathrm{SO}_{2}$ concentration in ppbv (isolines) and the projection of the wind speeds in the cross section (vectors). The sea-breeze front can be visualized by the vertical distribution of $\mathrm{SO}_{2}$ and at its top can be seen a sea-breeze cumuli.

\section{ACPD}

7, 15989-16022, 2007

Gaseous sulphur dioxide in a sea-breeze event

C. Talbot et al.

\section{Title Page}

\section{Abstract}

Conclusions

Tables

14

4

Back
Introduction

References

\section{Figures}

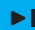

Close
Full Screen / Esc

Printer-friendly Version

Interactive Discussion 